\title{
Thermodynamic Modeling of Hydrogen Storage Capacity in Mg-Na Alloys
}

\author{
S. Abdessameud, M. Mezbahul-Islam, and M. Medraj \\ Department of Mechanical and Industrial Engineering, Concordia University, 1455 de Maisonneuve Boulevard West, QC, \\ Montreal, Canada H3G 1 M8 \\ Correspondence should be addressed to M. Medraj; mmedraj@encs.concordia.ca
}

Received 12 June 2014; Accepted 11 August 2014; Published 14 October 2014

Academic Editor: Edward Mikuli

Copyright (C) 2014 S. Abdessameud et al. This is an open access article distributed under the Creative Commons Attribution License, which permits unrestricted use, distribution, and reproduction in any medium, provided the original work is properly cited.

Thermodynamic modeling of the H-Mg-Na system is performed for the first time in this work in order to understand the phase relationships in this system. A new thermodynamic description of the stable $\mathrm{NaMgH}_{3}$ hydride is performed and the thermodynamic models for the $\mathrm{H}-\mathrm{Mg}, \mathrm{Mg}-\mathrm{Na}$, and $\mathrm{H}-\mathrm{Na}$ systems are reassessed using the modified quasichemical model for the liquid phase. The thermodynamic properties of the ternary system are estimated from the models of the binary systems and the ternary compound using CALPHAD technique. The constructed database is successfully used to reproduce the pressure-composition isotherms for $\mathrm{MgH}_{2}+10$ wt.\% $\mathrm{NaH}$ mixtures. Also, the pressure-temperature equilibrium diagram and reaction paths for the same composition are predicted at different temperatures and pressures. Even though it is proved that $\mathrm{H}-\mathrm{Mg}-\mathrm{Na}$ does not meet the DOE hydrogen storage requirements for onboard applications, the best working temperatures and pressures to benefit from its full catalytic role are given. Also, the present database can be used for thermodynamic assessments of higher order systems.

\section{Introduction}

Hydrogen stands as an ideal fuel for the future reducing the dependence on oil and the environmental problems arising from the use of fossil fuels. Hydrogen can be used for power generation through fuel cells. Hydrogen fuel cells have a wide range of potential applications ranging from microfuel cells that power portable electronics to mobile applications [1]. The transition to hydrogen energy is hindered by technical barriers related to storage problems. Solid state hydrogen storage materials, such as lightweight metal hydrides and complex and chemical hydrides, have been widely investigated due to their small volume, low equilibrium pressure, safety advantages, and high storage capacity [2-6].

Magnesium and its alloys stand as promising candidates for hydrogen storage. In fact, magnesium hydride $\mathrm{MgH}_{2}$ contains $7.6 \mathrm{wt} . \%$ hydrogen [4], but it suffers from extremely slow hydriding kinetics. A temperature of about $300^{\circ} \mathrm{C}$ is required for a plateau pressure of 1 bar at thermodynamic equilibrium, which corresponds to an enthalpy of formation of $-78 \mathrm{~kJ} / \mathrm{molH}_{2}[4]$. The investigations of magnesium hydrides found in the literature focus on decreasing desorption temperature, enhancing the kinetics and cycle life, and lowering their reactivity with air and oxygen [7-9]. Mixing with other compounds and/or incorporating new elements have been shown to be effective strategies to tune the thermodynamic properties of $\mathrm{MgH}_{2}[7,10]$. The literature shows that the search of new alloys, suitable for hydrogen storage, is somewhat a trial and error method, involving numerous experiments. Also, hydrogen is a flammable gas which makes this search more difficult. The effort and time of experiments can be reduced significantly with the application of thermodynamic calculation. Hence, a selfconsistent thermodynamic database of the $\mathrm{H}-\mathrm{Mg}$-Me system (Me is one metal or more) will be very useful for identifying the most promising hydrogen storage alloys and for studying the effect of adding minor elements or mixing hydrides on the storage capability.

In recent years, the Mg-based perovskite-type hydrides, especially $\mathrm{NaMgH}_{3}$, have received considerable attention for hydrogen storage applications [11-17]. In addition to its high gravimetric and volumetric hydrogen densities (6 wt.\% 
and $88 \mathrm{~kg} / \mathrm{m}^{3}$ ), $\mathrm{NaMgH}_{3}$ demonstrates reversible hydrogen storage properties [18]. The crystal structure of $\mathrm{NaMgH}_{3}$ has been identified as orthorhombic perovskite with the space group of Pnma ( $\mathrm{GdFeO}_{3}$-type structure) [15]. Recently, it has been found that $\mathrm{NaH}$ hydride addition greatly improves the hydrogen storage properties of $\mathrm{MgH}_{2}$ because of the formation of $\mathrm{NaMgH}_{3}$ [19]. Fast hydrogen mobility in $\mathrm{NaMgH}_{3}$ has been revealed by $\mathrm{H}$ NMR study and related to its perovskite structure [20]. Therefore, it is believed that, in a mixture of $\mathrm{MgH}_{2}$ and $\mathrm{NaMgH}_{3}$, hydrogen gas adsorption and dissociation are activated by $\mathrm{NaMgH}_{3}$ grains which offer fast diffusion pathway for hydrogen atoms into $\mathrm{MgH}_{2}[16$, 19]. Also, it has been found that $\mathrm{NaMgH}_{3}$ forms during the destabilization reactions of many complex hydrides [21-27].

Consequently, accurate thermodynamic description of $\mathrm{H}-\mathrm{Mg}-\mathrm{Na}$ system is required as a building block of a larger database of $\mathrm{H}-\mathrm{Mg}$-Me. In the present work, thermodynamic modeling is used to provide a self-consistent database which can be used to predict hydrogen storage properties of the $\mathrm{H}$ $\mathrm{Mg}-\mathrm{Na}$ system for the whole composition range. The $\mathrm{H}-\mathrm{Mg}$ $\mathrm{Na}$ system is modeled using FactSage software [28].

\section{Literature Review}

2.1. $\mathrm{H}-\mathrm{Mg}$ System. No complete experimental phase diagram of the $\mathrm{Mg}-\mathrm{H}$ system could be found in the literature. An extensive literature review of the $\mathrm{H}-\mathrm{Mg}$ system has been presented by San-Martin and Manchester [29] and later by Zeng et al. [30]. But some of the experimental data [31, 32] were not cited by San-Martin and Manchester [29] and are added in this work. Experimental investigations on phase equilibria were performed by different researchers $[29,33-$ 35]. Only one temperature-composition isobar profile at 1.013 bar was predicted by Shapovalov et al. [36]. The $\mathrm{H}-\mathrm{Mg}$ system consists of hcp-(Mg) (the interstitial solid solution of $\mathrm{H}$ in $\mathrm{Mg}$ ) and $\beta-\mathrm{MgH}_{2}$ in addition to the liquid and gas phases. Two invariant equilibria have been confirmed by San-Martin and Manchester [29] in this system, L $\rightarrow$ hcp$(\mathrm{Mg})+$ gas and hcp- $(\mathrm{Mg})+$ gas $\rightarrow \mathrm{MgH}_{2}$. According to Stampfer et al. [35], from the measured pressure-composition isotherms (PCI), the composition of $\beta-\mathrm{MgH}_{2}$ after a complete hydriding reaction was $\mathrm{MgH}_{1.99 \pm 0.01}$. In this work, this phase is treated as a stoichiometric compound. The equilibrium absorption/desorption pressure of the $\beta-\mathrm{MgH}_{2}$ was investigated by different authors [37-42]. According to Krozer and Kasemo [41], the equilibrium formation pressure of $\mathrm{MgH}_{2}$ is very close to its decomposition pressure. Stampfer et al. [35] collected 129 data points in the measurement of the dissociation pressures of $\beta-\mathrm{MgH}_{2}$ in the temperature range $587-849 \mathrm{~K}$ with uncertainties of 0.35 bar and $1 \mathrm{~K}$. These results are used in this work because they are self-consistent and in excellent agreement with the results published by Ellinger et al. [43], Reilly and Wiswall [44], and other groups [36, 4547]. The enthalpy and entropy of formation of $\beta-\mathrm{MgH}_{2}$ have been calculated from PCI measurements using Van't Hoff plot by many researchers $[35,43-48]$.

Wolf et al. [31] determined the standard entropy $\left(S_{0}\right.$ $\left.=30.64 \pm 0.05 \mathrm{JK}^{-1} \mathrm{~mol}^{-1}\right)$ and the specific heat capacity function, $c_{p}(T)=\left(2.8711+0.11061 T+68611 T^{-2}\right) \mathrm{JK}^{-1} \mathrm{~mol}^{-1}$, within the range $298-373 \mathrm{~K}$ for $\mathrm{MgH}_{2}$ using adiabatic low temperature calorimetry and differential scanning calorimetry (DSC). Bogdanović et al. [32] determined the average desorption enthalpy at an average temperature of $683 \mathrm{~K}$ using calorimetric measurements. They used the results published by Wolf et al. [31] to calculate the enthalpy and entropy of formation of $\mathrm{MgH}_{2}$. These results [31, 32] are used as first approximation in the present work together with the previously reported PCIs results.

Hydrogen solubility in magnesium has been investigated several times [34, 36, 42, 49-53]. Stampfer et al. [35] calculated the equilibrium hydrogen solubility in solid magnesium, hcp-( $\mathrm{Mg})$, at five different temperatures from the PCI measurement assuming that the decomposition of $\mathrm{MgH}_{2}$ was complete at the end of the isotherm. A modified Sieverts apparatus was used by Koeneman and Metcalfe [42] to determine the solubility of hydrogen in magnesium between 328 and $1048 \mathrm{~K}$. The results of Koeneman and Metcalfe [42] are in good agreement with those published later by Huang et al. [50] and Shapovalov et al. [34, 36]. Popovic and Piercy [53] measured the solubility of hydrogen in solid magnesium. But their [53] values are lower than those reported earlier $[33,35,41,49]$ and are not considered in the present work. The data obtained by Shapovalov et al. [36] using the conventional methods for high temperatures are also lower. Therefore these data [36] are not considered in this work because of the possible losses of hydrogen.

Thermodynamic modeling of the H-Mg system was conducted by Zeng et al. [30]. But the hydrogen solubility in the molten magnesium was neglected in their [30] work and the liquid phase was treated as an ideal solution. Recently, Harvey and Chartrand [54] modeled the hydrogen solubility in liquid magnesium using the modified quasichemical model taking into account the solubility of hydrogen in the liquid magnesium. Their optimized thermodynamic parameters for the liquid phase are used in the present work and, thus, the other phases are remodeled to be consistent with the new liquid and to take into account the new experimental data of Wolf et al. [31] and Bogdanović et al. [32].

2.2. $\mathrm{H}-\mathrm{Na}$ System. The H-Na system was reviewed by SanMartin and Manchester [55]. Based on some of the earlier studies [56-58], they [55] predicted that at the atmospheric pressure the maximum solubility of $\mathrm{H}$ in solid $\mathrm{Na}$ should be less than $8 \times 10^{-5}$ at.\%. Since no experimental measurement of the solubility could be found in the literature their [55] prediction will be used during optimization in the present work. The solubility of $\mathrm{H}$ in liquid $\mathrm{Na}$ was measured by several researchers [59-64] in the mid-1900s in the temperature range from 373 to $723 \mathrm{~K}$ at the atmospheric pressure. All these measurements showed a consistent trend of increased $\mathrm{H}$ solubility in liquid $\mathrm{Na}$ with increasing temperature. These results will be compared with the present thermodynamic modeling.

The H-Na system has one stable compound, $\mathrm{NaH}$. The melting point of $\mathrm{NaH}$ was determined by thermal analysis by Skuratov et al. [65] as $911 \pm 2 \mathrm{~K}$ at 107.3 bar and $911 \pm 2 \mathrm{~K}$ at 
207.3 bar. Another measurement by Klostermeier and Franck [66] showed the melting point of $\mathrm{NaH}$ to be $905 \pm 2 \mathrm{~K}$ at 106 bar which is in accord with Skuratov et al. [65]. The kinetic studies on the rate of reaction and thermal decomposition of $\mathrm{NaH}$ were carried out by $[67,68]$. Prochazka and Nedved [67] studied the effect of $\mathrm{CO}$ on $\mathrm{H}$ during the reaction and suggested the $\mathrm{CO}$ acts as a precursor. Gwyther and Whittingham [68] measured the rate of $\mathrm{H}$ removal from $\mathrm{Na}+\mathrm{NaH}$ mixtures by continuous evacuation and purging by argon in the temperature range of 533-693 K. They also reported the rate of $\mathrm{H}$ desorption from unsaturated solutions of $\mathrm{NaH}$ in liquid $\mathrm{Na}$ at $\leq 673 \mathrm{~K}$.

Crystallographic study of the $\mathrm{Na}-\mathrm{H}$ system was performed by several researchers [69-72] using X-ray diffraction. $\mathrm{NaH}$ has an $f c c$ crystal structure $(F m \overline{3} m)$ with a prototype of $\mathrm{NaCl}$. The XRD measurement by Kuznetsov and Shkrabkina [72] at different temperatures did not show any phase transformation of $\mathrm{NaH}$ up to the decomposition temperature. They [72] also observed that the lattice parameter of $\mathrm{NaH}$ increases linearly from $a=0.4872 \mathrm{~nm}$ at room temperature to $0.5000 \mathrm{~nm}$ at $673 \mathrm{~K}$. Later San-Martin and Manchester [55] reported the following equation to fit the data of Kuznetsov and Shkrabkina [72]:

$$
a=0.487017+0.32 \times 10^{-4} T \quad(293<T<683 \mathrm{~K}) .
$$

Qiu et al. [73] also calculated the lattice parameter of $\mathrm{NaH}$ as $0.4857 \mathrm{~nm}$ using the first principle which is close to the reported values by [72].

The enthalpy of formation of $\mathrm{NaH}$ was determined by several groups using two different techniques: calorimetric methods [74-77] and dissociation pressure data [57, 65, 78]. In the calorimetric methods the enthalpy values are measured from the difference between the heat of reaction of $\mathrm{NaH}$ and that of $\mathrm{Na}$, with water [55] as it is the most common medium due to the well-known $c_{p}$. For the second method, the dissociation pressures of hydrides are measured usually over a temperature range. Using these data, the enthalpy of formation at the atmospheric pressure is determined from the slope of the Van't Hoff plot $(\log P$ versus $1 / T)$ [55]. The enthalpy of formation of $\mathrm{NaH}$ that was reported by various groups $[57,75,76,78]$ is fairly in agreement with each other and will be compared with the present calculation. The heat capacity of $\mathrm{NaH}$ was measured by Sayre and Beaver [79] in the temperature range from 60 to $90 \mathrm{~K}$ using an adiabatic calorimeter. Their [79] reported $c_{p}$ values will be compared with the present calculation.

A partial phase diagram of the $\mathrm{Na}-\mathrm{H}$ system was presented by Predel [80]. Later Qiu et al. [73] assessed the H-Na system combining experimental data from the literature and first principle calculation based on density functional theory to supplement the thermodynamic properties of this system. Qiu et al. [73] modeled the $\mathrm{Na}-\mathrm{H}$ liquid with the random solution model and bcc phase with the sublattice model. Heat capacity in the temperature range from 0 to $2000 \mathrm{~K}$ was calculated by first principle calculations. They [73] also presented the heat of formation of $\mathrm{NaH}$, decomposition pressure, and hydrogen solubility in liquid $\mathrm{Na}$.
2.3. $M g-N a$ System. The experimental work and thermodynamic modeling of the $\mathrm{Mg}-\mathrm{Na}$ system were carried out by several groups [81-85]. The main feature of $\mathrm{Mg}-\mathrm{Na}$ system is the large immiscibility in the liquid phase. No experimental data regarding the critical temperature as well as the shape of the immiscibility gap could be found in the literature. The solubility of $\mathrm{Na}$ in solid $\mathrm{Mg}$ as well as $\mathrm{Mg}$ in solid $\mathrm{Na}$ is negligible. Pelton [84] estimated $\sim 0.5$ at.\% Na solubility in $\mathrm{Mg}$ by assuming Henrian behavior of the solution and employing Van't Hoff equation to back-calculate the solubility. This is rather small solubility and since there is no experimental evidence, no solubility of $\mathrm{Na}$ in $\mathrm{Mg}$ is considered in the present work.

Mathewson [81] employed thermal analysis and determined the composition and temperature of the monotectic (liquid $1 \rightarrow$ liquid $2+$ hcp- $(\mathrm{Mg})$ ) reaction to be 2 at. $\% \mathrm{Na}$ and $911 \mathrm{~K}$. He [81] reported the composition of liquid 2 to be $\sim 98.6$ at.\% $\mathrm{Na}$ at $911 \mathrm{~K}$. Klemm and Kunze [83] reported MgNa phase diagram with the monotectic temperature of $910 \mathrm{~K}$. Although they [83] mentioned this as a peritectic reaction instead of monotectic, the temperature of the thermal event agreed well with the results of Mathewson [81]. Pelton [84] extracted the composition of the monotectic liquid 2 from Klemm and Kunze's [83] reported phase diagram as $\sim 92.7$ at.\% $\mathrm{Na}$ and used this value in his assessment. The composition ( $~ 98.6$ at.\% $\mathrm{Na})$ reported by Mathewson [81] could be associated with higher error due to the use of a glass container which usually reacts with $\mathrm{Mg}-\mathrm{Na}$ liquid [84]. Hence during optimization the composition of liquuid 2 reported by Klemm and Kunze [83] will be used since they used iron crucibles. Lantratov [82] reported the temperature dependent solubility of $\mathrm{Na}$ in liquid $\mathrm{Mg}$. The solubility of $\mathrm{Na}$ increases from 2.1 at. $\%$ at $911 \mathrm{~K}$ to $2.7 \pm 0.1$ at. $\% \mathrm{Na}$ at $973 \mathrm{~K}$.

Lantratov [82] measured the activities of $\mathrm{Na}$ and $\mathrm{Mg}$ in the liquid along the complete composition range by EMF method at $973 \mathrm{~K}$ which exhibited strong positive deviation from ideality due to the limited solubility. In a recent study, Zhang et al. [85] presented a thermodynamic model of the $\mathrm{Mg}-\mathrm{Na}$ system as the constituent binary of the Al-Mg-Na ternary system. They [85] employed the random solution model for the liquid phase and calculated the $\mathrm{Mg}-\mathrm{Na}$ phase diagram and the activities of $\mathrm{Mg}$ and $\mathrm{Na}$ in the liquid.

2.4. $\mathrm{H}-\mathrm{Mg}-\mathrm{Na}$ System. Only one ternary compound, $\mathrm{NaMgH}_{3}$, has been reported in the $\mathrm{H}-\mathrm{Mg}-\mathrm{Na}$ system. The standard enthalpy of formation of $\mathrm{NaMgH}_{3}$ was determined by Bouamrane et al. [13] as $-231 \pm 4 \mathrm{~kJ} / \mathrm{mol}$, by calorimetry using its reaction with diluted hydrochloric acid $(0.5 \mathrm{M}$ $\mathrm{HCl}$ ). The hydrogen desorption and absorption properties of $\mathrm{NaMgH}_{3}$ have been investigated for the first time by Ikeda et al. [18] using XRD, thermogravimetry, differential thermal analysis, and hydrogen pressure-composition PCI measurements. They $[18,86]$ reported that $5.8 \pm 0.2 \mathrm{wt} . \%$ hydrogen has been released from the sample during two endothermic reactions. Hydrogen was desorbed after only $8 \mathrm{~min}$ at $673 \mathrm{~K}$ and $\mathrm{NaMgH}_{3}$ formed under 10 bar of hydrogen at $673 \mathrm{~K}[18]$. Only one PC isotherm at $673 \mathrm{~K}$ was reported [18] showing two plateau pressures of 1.5 and 
0.4 bar confirming that $\mathrm{NaMgH}_{3}$ decomposes in two steps according to the following reactions [18]:

$$
\begin{gathered}
\mathrm{NaMgH}_{3} \longrightarrow \mathrm{NaH}+\mathrm{Mg}+\mathrm{H}_{2} \quad 4 \text { wt. } \% \mathrm{H}_{2} \\
\mathrm{NaH} \longrightarrow \mathrm{Na}(\mathrm{l})+\frac{1}{2} \mathrm{H}_{2} \quad 2 \text { wt. } \% \mathrm{H}_{2}
\end{gathered}
$$

The enthalpy change of reaction (2) was calculated by Ikeda et al. [18], using Van't Hoff plot; $\Delta H(298 \mathrm{~K})=88 \mathrm{~kJ} / \mathrm{molH}_{2}$. Using this value and the reported standard heat of formation of $\mathrm{NaH},-114.1 \mathrm{~kJ} / \mathrm{molH}_{2}$ [87], as enthalpy change for reaction (3), the standard enthalpy of formation of $\mathrm{NaMgH}_{3}$ was estimated to be $-96.7 \mathrm{~kJ} / \mathrm{molH}_{2}[18]$ or $-145 \mathrm{~kJ} / \mathrm{mol}$. PCIs of $\mathrm{NaMgH}_{3}$ during decomposition were reported by Komiya et al. [17] at 673, 698, and $723 \mathrm{~K}$. For the isotherm measured at $673 \mathrm{~K}$, the plateau pressures were around 1 and 0.4 bar for reactions (2) and (3), respectively. The enthalpy and the entropy changes of these reactions have been calculated using the Van't Hoff plot. By calculating the sum of the enthalpy changes of reactions (2) and (3), the standard enthalpy of formation of $\mathrm{NaMgH}_{3}$ was wrongly estimated by these authors to be $-210 \pm 17 \mathrm{~kJ} / \mathrm{molH}_{2}$ [17]; they did not pay attention to the units used $\left(\mathrm{kJ} / \mathrm{molH}_{2}\right)$. Hence, heat of formation of this compound will be recalculated in the present work using their [17] enthalpy values for reactions (2) and (3). PCIs of $\mathrm{NaMgH}_{3}$ during decomposition were reported by Ikeda et al. [15] at 653, 673, and $693 \mathrm{~K}$. Pottmaier et al. [27] investigated the thermodynamic properties of $\mathrm{NaMgH}_{3}$ using high pressure DSC, PCI measurements, and density functional theory calculations (DFT). Enthalpy and entropy of reaction (2) were calculated from PCI measurements at 650, 670, 680, 700, and $723 \mathrm{~K}$ [27]. Pottmaier et al. [27] used their results together with the experimental and calculated values from the literature to estimate the thermodynamic properties of $\mathrm{NaMgH}_{3}$ using the CALPHAD approach. It should be pointed out that, for the PCIs published by Ikeda et al. [15], Komiya et al. [17], and Pottmaier et al. [27], the plateaus were slopped and very limited data points were collected within them. In addition to that, the quality of the data given by Pottmaier et al. [27] is poor especially at 650 and $670 \mathrm{~K}$; the plateaus are not flat with large pressure variations. Slow kinetics, an insufficient time for each equilibrium measurement, or an insufficient pressure resolution might be the causes of these problems and might have led to erroneous enthalpy and entropy determination from Van't Hoff plot. Later on, Sheppard et al. [88] investigated the kinetic and thermodynamic data of $\mathrm{NaMgH}_{3}$ decomposition. PCIs showing the first reaction decomposition at 671.4, 683.8, 691.9, 702.8 , and $712.9 \mathrm{~K}$ were reported. All the above-mentioned problems have been avoided by Sheppard et al. [88] by waiting longer (more than $2 \mathrm{~h}$ ) to reach true thermodynamic equilibrium for each sorption step. The plateau curves were wide and flat with negligible hysteresis. For all these reasons the experimental data reported by Sheppard et al. [88] are used in the present optimization of the $\mathrm{H}-\mathrm{Mg}-\mathrm{Na}$ system. The thermodynamic properties of $\mathrm{NaMgH}_{3}$ obtained from PCIs and DSC by different authors are summarized in Table 5. Since there is no information regarding the homogeneity range of $\mathrm{NaMgH}_{3}$ in the literature, this compound is treated as stoichiometric in this work. Thermodynamic modeling of the $\mathrm{H}-\mathrm{Mg}-\mathrm{Na}$ system for the whole composition range is conducted for the first time in the present study.

\section{Thermodynamic Modeling}

3.1. Pure Elements. The Gibbs energy functions of the pure elements (Mg, Na) are taken from the SGTE (Scientific Group Thermo data Europe) compilation of Dinsdale [89]. These data are taken in reference to the Stable Element Reference (SER) at $298.15 \mathrm{~K}$ and 1 bar. Liquid monoatomic hydrogen is not stable under normal conditions; its Gibbs energy has been estimated by Roy and Rodgers [56] and is reported in Table 1. The $c_{p}$ values of the gases included in this study, that is, $\mathrm{H}_{2}, \mathrm{H}, \mathrm{Mg}, \mathrm{Mg}_{2}, \mathrm{MgH}, \mathrm{Na}, \mathrm{Na}_{2}$, and $\mathrm{NaH}$, are taken from NIST-JANAF thermochemical tables [90] compiled by FactPS database [28].

3.2. Stoichiometric Compounds. The Gibbs energy of a binary stoichiometric phase is given by

$$
G^{\phi}=x_{i}^{0} G_{i}^{\phi_{1}}+x_{j}{ }^{0} G_{i}^{\phi_{2}}+\Delta G_{f},
$$

where $x_{i}$ and $x_{j}$ are mole fractions of the components $i$ and $j$ of the compound denoted by $f .{ }^{0} G_{i}^{\phi_{1}}$ and ${ }^{0} G_{i}^{\phi_{2}}$ are the Gibbs energy of components $i$ and $j$ in their standard state. $\Delta G_{f}=$ $a+b T$ is the Gibbs energy of formation per mole of atoms of the stoichiometric compound. The parameters $a$ and $b$ are obtained by optimization. The stoichiometric compounds in the $\mathrm{H}-\mathrm{Mg}-\mathrm{Na}$ system are $\mathrm{MgH}_{2}, \mathrm{NaH}$, and $\mathrm{NaMgH}_{3}$.

3.3. Liquid Phase. Modified quasichemical model is used to describe the liquid phase for all the binaries. This model uses the energy of pair formation to define the excess Gibbs energy. According to [91], the excess energy is expressed as

$$
\Delta g_{A B}=\Delta g_{A B}^{0}+\sum_{i \geq 1} g_{A B}^{i 0} X_{A A}^{i}+\sum_{j \geq 1} g_{A B}^{0 j} X_{B B}^{j},
$$

where $\Delta g_{A B}^{0}, \Delta g_{A B}^{i 0}$, and $\Delta g_{A B}^{0 j}$ are the parameters of the model and are expressed as functions of temperature $\left(\Delta g_{A B}^{0}=\right.$ $a+b T)$. The short range ordering in the liquid is expressed by the atom to atom coordination number " $Z$ " and is given by

$$
\begin{aligned}
\frac{1}{Z_{A}} & =\frac{1}{Z_{A A}^{A}}\left(\frac{2 n_{A A}}{2 n_{A A}+n_{A B}}\right)+\frac{1}{Z_{A B}^{A}}\left(\frac{n_{A B}}{2 n_{A A}+n_{A B}}\right), \\
\frac{1}{Z_{B}} & =\frac{1}{Z_{B B}^{B}}\left(\frac{2 n_{B B}}{2 n_{B B}+n_{A B}}\right)+\frac{1}{Z_{B A}^{B}}\left(\frac{n_{A B}}{2 n_{B B}+n_{A B}}\right) .
\end{aligned}
$$

$Z_{A A}^{A}$ and $Z_{A B}^{A}$ are the values of $Z_{A}$ when all the nearest neighbors of $A$ atom are $A$ 's and when all the nearest neighbors of $A$ atom are $B$ 's, respectively. The same applies to $Z_{B B}^{B}$ and $Z_{B A}^{B}$. All binary liquid thermodynamic parameters have been interpolated using the asymmetric Kohler-Toop technique [91]. According to Qiao et al. [92], $\mathrm{H}$ is singled out as the asymmetric component since Mg-Na system shows significantly different thermodynamic characteristics than both $\mathrm{Mg}-\mathrm{H}$ and $\mathrm{Na}-\mathrm{H}$. In the current work, no ternary parameters are added to the liquid model. 
TABLE 1: Optimized model parameters for the different phases in the $\mathrm{H}-\mathrm{Mg}-\mathrm{Na}$ system (J/mole).

\begin{tabular}{|c|c|c|}
\hline Phase & Model & Parameters \\
\hline \multirow{6}{*}{ Liquid } & \multirow{6}{*}{ MQM } & $g_{\mathrm{H}(1)}^{0}=74,266.7-26.2456 T+20.7856 T \ln T$ \\
\hline & & $Z_{\mathrm{MgH}}^{\mathrm{Mg}}=Z_{\mathrm{MgH}}^{\mathrm{H}}=6, \Delta g_{\mathrm{MgH}}^{0}=-18,049.78$ \\
\hline & & $Z_{\mathrm{NaH}}^{\mathrm{Na}}=Z_{\mathrm{NaH}}^{\mathrm{H}}=6, \Delta g_{\mathrm{NaH}}^{0}=-39,245.92+8.45 T$ \\
\hline & & $\Delta g_{\mathrm{NaH}}^{10}=12,133.6-0.711 T$ \\
\hline & & $\Delta g_{\mathrm{NaH}}^{01}=-66,944+8.368 T$ \\
\hline & & $Z_{\mathrm{MgNa}}^{\mathrm{Mg}}=4.5, Z_{\mathrm{MgNa}}^{\mathrm{Na}}=6, \Delta g_{\mathrm{MgNa}}^{0}=7,660.0+2.9 T$ \\
\hline \multirow{5}{*}{ hcp-(Mg) } & \multirow{5}{*}{$\begin{array}{l}\text { Sublattice } \\
(\mathrm{Mg}, \mathrm{Na})_{2}(\mathrm{H}, \mathrm{Va})_{1}\end{array}$} & ${ }^{0} G_{\mathrm{Mg}: \mathrm{H}}^{\mathrm{Mg}_{2} \mathrm{H}}=173,217.6-242.672 T+2 G\left(\mathrm{Mg}_{\mathrm{cph}}\right)+1 / 2 G\left(\mathrm{H}_{2}\right.$, gas $)$ \\
\hline & & ${ }^{0} G_{\mathrm{Na}: \mathrm{H}}^{\mathrm{Na}_{2} \mathrm{H}}=2 G\left(\mathrm{Na}_{\mathrm{cph}}\right)+1 / 2 G\left(\mathrm{H}_{2}\right.$, gas $)$ \\
\hline & & ${ }^{0} G_{\mathrm{Mg}: \mathrm{Va}}^{\mathrm{Mg}_{2}}=2 G\left(\mathrm{Mg}_{\mathrm{cph}}\right)$ \\
\hline & & ${ }^{0} G_{\mathrm{Na}: \mathrm{Va}}^{\mathrm{Na}_{2}}=2 G\left(\mathrm{Na}_{\mathrm{cph}}\right)$ \\
\hline & & ${ }^{0} L_{\mathrm{Mg}, \mathrm{Na}: \mathrm{Va}}^{\mathrm{cph}}=79,496+16.736 \mathrm{~T}$ \\
\hline \multirow{5}{*}{ bcc- $(\mathrm{Na})$} & \multirow{5}{*}{$\begin{array}{l}\text { Sublattice } \\
(\mathrm{Na}, \mathrm{Mg})_{1}(\mathrm{H}, \mathrm{Va})_{3}\end{array}$} & ${ }^{0} G_{\mathrm{Na}: \mathrm{H}}^{\mathrm{NaH}_{3}}=G\left(\mathrm{Na}_{\mathrm{bcc}}\right)+3 / 2 G\left(\mathrm{H}_{2}\right.$, gas $)$ \\
\hline & & ${ }^{0} G_{\mathrm{Na}: \mathrm{H}}^{\mathrm{MgH}_{3}}=G\left(\mathrm{Mg}_{\mathrm{bcc}}\right)+3 / 2 G\left(\mathrm{H}_{2}\right.$, gas $)$ \\
\hline & & ${ }^{0} G_{\mathrm{Na}: \mathrm{Va}}^{\mathrm{Na}}=G\left(\mathrm{Na}_{\mathrm{bcc}}\right) ;{ }^{0} G_{\mathrm{Mg}: \mathrm{Va}}^{\mathrm{Mg}}=G\left(\mathrm{Mg}_{\mathrm{bcc}}\right)$ \\
\hline & & ${ }^{0} L_{\mathrm{Na}: \mathrm{H}, \mathrm{Va}}^{\mathrm{bcc}}=-5,569.8 ;{ }^{1} L_{\mathrm{Na}: \mathrm{H}, \mathrm{Va}}^{\mathrm{bcc}}=-2,092.9$ \\
\hline & & ${ }^{0} L_{\mathrm{Na}, \mathrm{Mg}: \mathrm{Va}}^{\mathrm{bcc}}=30,000$ \\
\hline \multirow{2}{*}{$\mathrm{MgH}_{2}$} & \multirow{2}{*}{ Stoichiometric } & ${ }^{\text {Solid }} G_{\mathrm{MgH}_{2}}^{0}=-82,842.15+25.42 T-2.87 T \ln T-55.30 \times 10^{-3} T^{2}-34,305.5 T^{-1}$ \\
\hline & & $298.15 \leq T \leq 2000$ \\
\hline \multirow{2}{*}{$\mathrm{NaH}$} & \multirow{2}{*}{ Stoichiometric } & ${ }^{\text {Solid }} G_{\mathrm{NaH}}^{0}=-75,767.99+293.72 T-48.69 T \ln T-0.26 \times 10^{-3} T^{2}+1.80 \times 10^{-8} T^{3}+632,658.0 T^{-1}$ \\
\hline & & $298.15 \leq T \leq 2000$ \\
\hline \multirow{2}{*}{$\mathrm{NaMgH}_{3}$} & \multirow{2}{*}{ Stoichiometric } & ${ }^{\text {Solid }} G_{\mathrm{NaMgH}_{3}}=-157,905.82+185.83 T-33.6 T \ln T-61.27 \times 10^{-3} T^{2}$ \\
\hline & & $298.15 \leq T \leq 2000$ \\
\hline
\end{tabular}

3.4. Gas Phase. In the pressure range of interest, the nonideal contribution of pressure to the Gibbs energy for the gases is very small. Therefore, the gases included in this work are taken as ideal gases. The gas phase is described by the ideal solution model as

$$
G=x_{i} G_{i}^{\phi}+x_{j} G_{j}^{\phi}+R T\left[x_{i} \ln x_{i}+x_{j} \ln x_{j}\right],
$$

where $i$ and $j$ are the gas constituents, $G_{i}^{\phi}={ }^{0} G_{i}^{\phi}+R T \operatorname{Ln} P$, and $P$ is the pressure.

3.5. Solid Solution Phases. Hydrogen atoms occupy interstitial positions in the solid magnesium, hcp- $(\mathrm{Mg})$, and sodium, bcc- $(\mathrm{Na})$. These phases are described by a two-sublattice model where the first sublattice is occupied by the metal atoms and the second one by hydrogen atoms and vacancies, $(\mathrm{M})_{a}(\mathrm{H}, \mathrm{Va})_{c}$. The Gibbs energy is described by the equations:

$$
\begin{aligned}
G & =G^{\mathrm{ref}}+G^{\text {ideal }}+G^{\text {excess }}, \\
G^{\mathrm{ref}} & =\sum y_{i}^{l} y_{j}^{m} \cdots y_{k}^{q 0} G_{(i: j \ldots \cdot k)},
\end{aligned}
$$

$$
\begin{gathered}
G^{\text {ideal }}=R T \sum_{l} f_{l} \sum_{i} y_{i}^{l} \ln y_{i}^{l}, \\
G^{\text {excess }}=\sum y_{i}^{l} y_{j}^{l} y_{k}^{m} \sum_{\gamma=0}{ }^{\gamma} L_{(i, j): k} \times\left(y_{i}^{l}-y_{j}^{l}\right)^{\gamma},
\end{gathered}
$$

where $i, j, \ldots, k$ are components or vacancy and $l, m$, and $q$ represent sublattices. $y_{i}^{l}$ is the site fraction of component $i$ on sublattice $l . f_{l}$ is the fraction of sublattice $l$ relative to the total lattice sites. ${ }^{0} G_{(i: j \ldots . k)}$ represents a real or a hypothetical compound energy. ${ }^{\gamma} L_{(i, j)}$ represent the interaction parameters which describe the interaction within the sublattice. According to Frisk [93] the number of sites on each sublattice $(\mathrm{M})_{a}(\mathrm{H}, \mathrm{Va})_{c}$ is $a=2$ and $c=1$ for the hcp-(Mg) phase and $a=1$ and $c=3$ for bcc-(Na) phase. To allow for the solubility of $\mathrm{Na}$ in hcp-( $\mathrm{Mg})$ and $\mathrm{Mg}$ in bcc-(Na), $\mathrm{Mg}$ and $\mathrm{Na}$ are allowed to mix randomly in the first sublattice. Therefore, the hcp- $(\mathrm{Mg})$ phase and bcc- $(\mathrm{Na})$ in the ternary system are described by the two sublattices $(\mathrm{Mg}, \mathrm{Na})_{2}(\mathrm{H}, \mathrm{Va})_{1}$ and $(\mathrm{Na}, \mathrm{Mg})_{1}(\mathrm{H}, \mathrm{Va})_{3}$, respectively. 
TABLE 2: Enthalpy and entropy of formation of $\mathrm{MgH}_{2}$.

\begin{tabular}{lccc}
\hline$\Delta H\left(\mathrm{~kJ} / \mathrm{molH}_{2}\right)$ & $\Delta S\left(\mathrm{~J} / \mathrm{molH}_{2} \cdot \mathrm{K}\right)$ & $\begin{array}{c}\text { Temperature range } \\
(\mathrm{K})\end{array}$ & Reference \\
\hline-77.3 & -136.9 & 298 & This work \\
$-77.4 \pm 4$ & $-138 \pm 3$ & $549-623$ & {$[44]$} \\
-74.4 & -135 & $587-849$ & {$[35]$} \\
-70 & -126 & $573-673$ & {$[48]$} \\
-78.2 & - & $573-616$ & {$[47]$} \\
-78.31 & -140.07 & $513-633$ & {$[46]$} \\
-79 & - & $575-629$ & {$[45]$} \\
-66.9 & - & 450 & {$[43]$} \\
-70.7 & -119 & 590 & {$[38]$} \\
-76.2 & - & 574 & {$[94]$} \\
$-74.05 \pm 1.3$ & - & 683 & {$[32]$} \\
\hline
\end{tabular}

\section{Results and Discussion}

The thermodynamic parameters optimized in the present work for the H-Mg-Na system are given in Table 1.

4.1. H-Mg System. The optimized thermodynamic parameters obtained by Harvey and Chartrand [54] using the MQM for the liquid phase are used in the present work. The hcp- $(\mathrm{Mg})$ is modeled using $(\mathrm{Mg})_{2}(\mathrm{H}, \mathrm{Va})_{1}$ two-sublattice model [93] as discussed in Section 3.5. No excess terms have been employed to represent hcp- $(\mathrm{Mg}) . \mathrm{MgH}_{2}$ is considered a stoichiometric compound. The gas species $\mathrm{H}, \mathrm{H}_{2}, \mathrm{Mg}, \mathrm{Mg}_{2}$, and $\mathrm{MgH}$ are treated as ideal gases. All the parameters for this system are listed in Table 1.

The calculated enthalpy and entropy of formation of magnesium hydride $\mathrm{MgH}_{2}$ are given in Table 2 together with experimental data from the literature. Very good consistency can be seen between the calculated values and the experimental data $[31,34,37,42-47,93]$ except for some deviation from the results published by Selvam et al. [38], Ellinger et al. [43], and Pedersen et al. [48]. Considering the consistency among the other six works, this deviation can be related to the quality of the PCIs and the slow kinetics which can lead to erroneous values of the equilibrium pressures. The calculated Mg-rich part of the $\mathrm{Mg}-\mathrm{H}$ phase diagram at 1 bar is presented in Figure 1(a) compared with experimental hydrogen solubility data in solid magnesium. The entire phase diagram at 1 bar is shown in Figure 1(b). It can be seen in Figure 1(a) that there is a good agreement between the calculated phase diagram at 1 bar and the selected experimental data except for the results of Popovic and Piercy [53] who differed from otherwise consistent results of $[33,35,41,49]$. According to the present calculations, the eutectic type reaction $\mathrm{L} \rightarrow \mathrm{hcp}-(\mathrm{Mg})+$ gas occurs at 0.0923 at. $\%$ hydrogen and $922 \mathrm{~K}$ which agrees well with that calculated by Zeng et al. $(0.093$ at. $\% \mathrm{H}$ and $922.8 \mathrm{~K})$ [30]. There is no measured decomposition temperature for $\mathrm{MgH}_{2}$ at the atmospheric pressure. However, the present work predicts that $\mathrm{MgH}_{2}$ decomposes to hcp- $(\mathrm{Mg})$ and $\mathrm{H}_{2}$ at $557.88 \mathrm{~K}$; this value is about $3 \mathrm{~K}$ lower than that predicted by Zeng et al. [30].
The calculated dissociation pressure of $\mathrm{MgH}_{2}$ as function of temperature is presented in Figure 2(a) which shows good agreement with the experimental data from the literature. The present results show that the thermodynamic functions used in this work describe the $\mathrm{H}-\mathrm{Mg}$ system in a broader pressure range more accurately than those reported by Zeng et al. [30]. In fact, Zeng et al. [30] unlike the current work did not achieve agreement with the experimental results above 150 bar. They blamed this inconsistency on the experimental data. The pressure-temperature diagram of $\mathrm{MgH}_{2}$ is presented in Figure 2(b) to show the stability of the different phases. It is predicted that $\mathrm{MgH}_{2}$ decomposes directly to liquid and gas above $919.5 \mathrm{~K}$ and 618.8 bar.

In order to compare with the experimental data of [35, 43], the $\mathrm{H}-\mathrm{Mg}$ phase diagrams at 30.48 bar and 236 bar are also calculated in the present work as shown in Figures 3(a) and 3(b), respectively. The dissociation temperature of $\mathrm{MgH}_{2}$ is predicted to be $700 \mathrm{~K}$ at $30.48 \mathrm{bar}$ and $832 \mathrm{~K}$ at $236 \mathrm{bar}$ which agrees very well with the values reported by Stampfer et al. [35] (700 K at 30.48 bar) and by Ellinger et al. [43] (834 K at 236 bar). It can be seen in Figure 3 that the temperature of the reaction $\mathrm{L} \rightarrow \mathrm{hcp}-(\mathrm{Mg})+$ gas does not change a lot with pressure.

4.2. H-Na System. The liquid phase of the $\mathrm{H}-\mathrm{Na}$ system is modeled using the modified quasichemical model. The solution has been considered to be random with no preferential short range ordering. The parameters of the model are determined considering the experimental data of $\mathrm{H}$ solubility in liquid $\mathrm{Na}$. The bcc- $(\mathrm{Na})$ is modeled using the compound energy formalism employing $(\mathrm{Na})_{1}(\mathrm{H}, \mathrm{Va})_{3}$ two-sublattice model [93] as mentioned in Section 3.5. This model has been adopted from Qiu et al. [73]. Two excess terms are used to describe this phase. $\mathrm{NaH}$ is considered a stoichiometric compound. The " $c_{p}$ " ranges $(0<T<298.15 \mathrm{~K}$ and 298.15 $<T<2000 \mathrm{~K}$ ) of solid $\mathrm{NaH}$ have been optimized in this work to comply with the experimental data of the phase diagram as well as the thermodynamic properties. The gas species $\mathrm{H}, \mathrm{H}_{2}, \mathrm{Na}, \mathrm{Na}_{2}$, and $\mathrm{NaH}$ are treated as ideal gases. All the parameters for this system are listed in Table 1 .

The calculated phase diagram of $\mathrm{H}-\mathrm{Na}$ system at 1 bar is presented in Figure 4. There is only one intermediate compound $\mathrm{NaH}$ in the system which decomposes at $700 \mathrm{~K}$ to liquid and gas. The $\mathrm{H}$ solubility in liquid $\mathrm{Na}$ has been found to be $\sim 0.23$ at. $\%$ at $700 \mathrm{~K}$ which is in good agreement with the proposed solubility limit of $\sim 0.2$ at.\% by San-Martin and Manchester [55].

In order to visualize the impact of pressure on the $\mathrm{H}$ solubility in liquid $\mathrm{Na}$, the $\mathrm{Na}-\mathrm{H}$ phase diagram has been calculated at 150 bar and 200 bar as shown in Figures 5(a) and $5(\mathrm{~b})$. It can be seen that the solubility increases from $\sim 0.23$ at.\% (700 K) to $\sim 4.0$ at.\% (983 K) from the ambient pressure to the 200 bar. The melting temperature of $\mathrm{NaH}$ is $911 \mathrm{~K}$ and $905 \mathrm{~K}$ at 200 and 115 bar, respectively, in the present work. This is in agreement with the measured value of $911 \pm 2 \mathrm{~K}$ at 207.3 bar by Skuratov et al. [65] and $905 \pm 2 \mathrm{~K}$ at 106 bar by Klostermeier and Franck [66]. The critical temperature $\left(T_{c}\right)$ for the immiscibility in the liquid is $1569 \mathrm{~K}$ in the present calculation as shown by the dotted line in Figure 5(b) which 


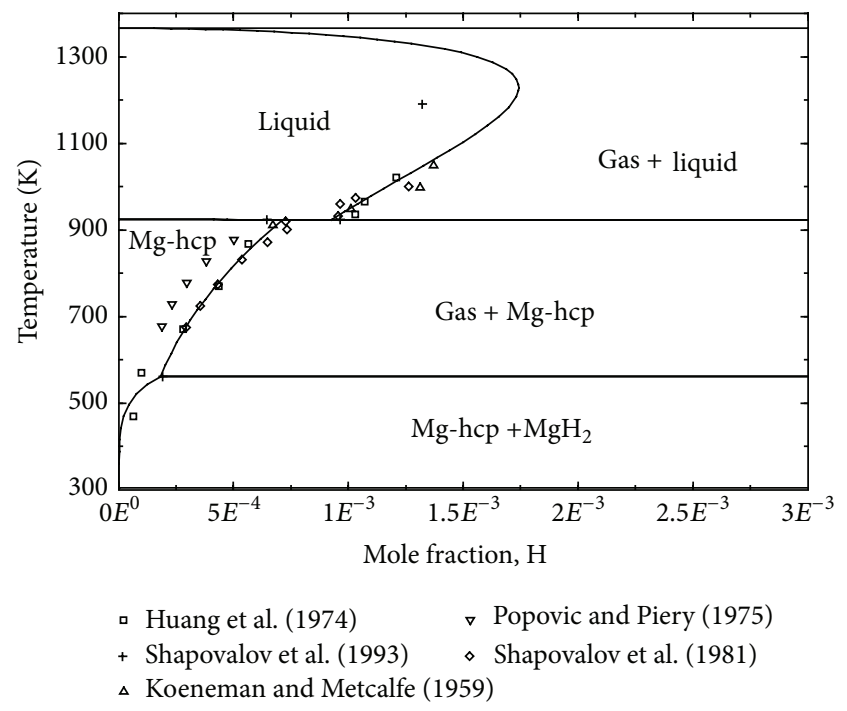

(a)

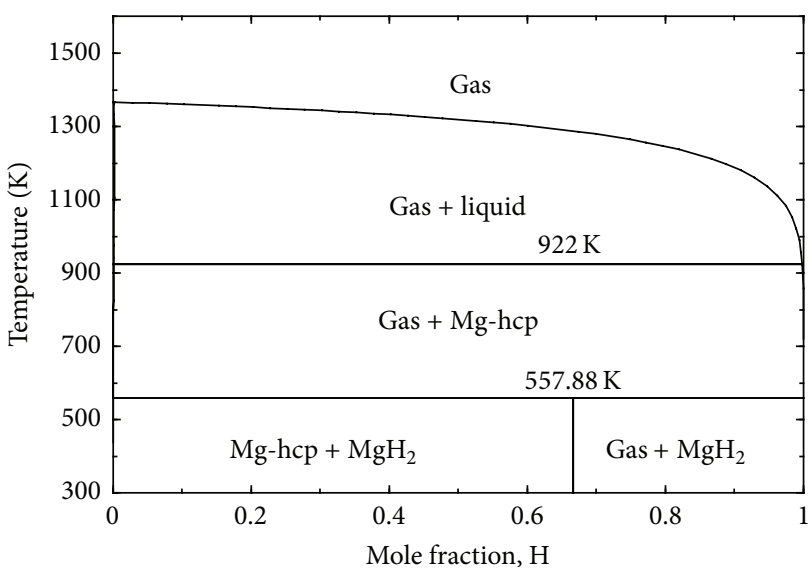

(b)

FIGURE 1: Calculated Mg-rich part of Mg-H phase diagram at 1 bar compared with experimental hydrogen solubilities in solid magnesium data from literature (a) and the calculated $\mathrm{Mg}-\mathrm{H}$ phase diagram over the entire temperature range (b) at 1 bar.

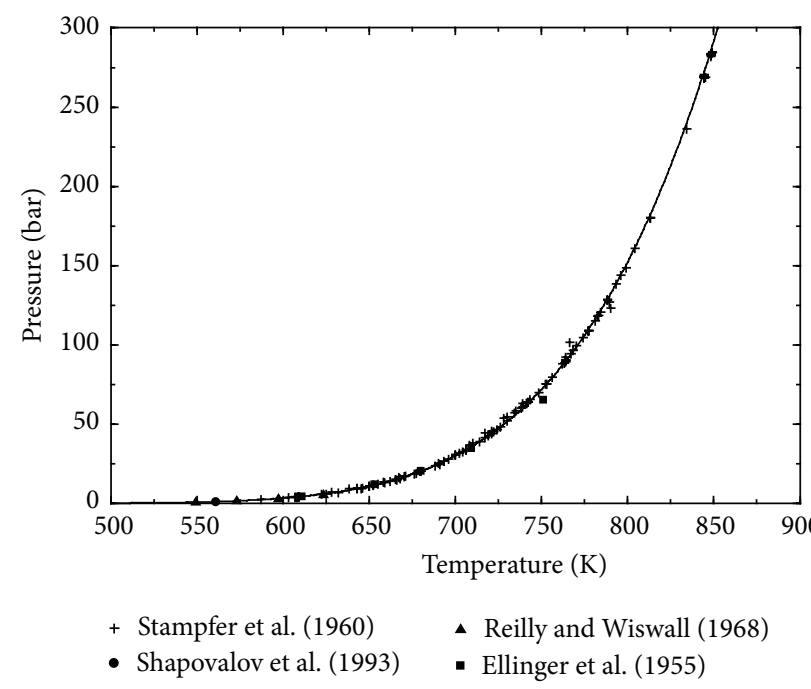

(a)

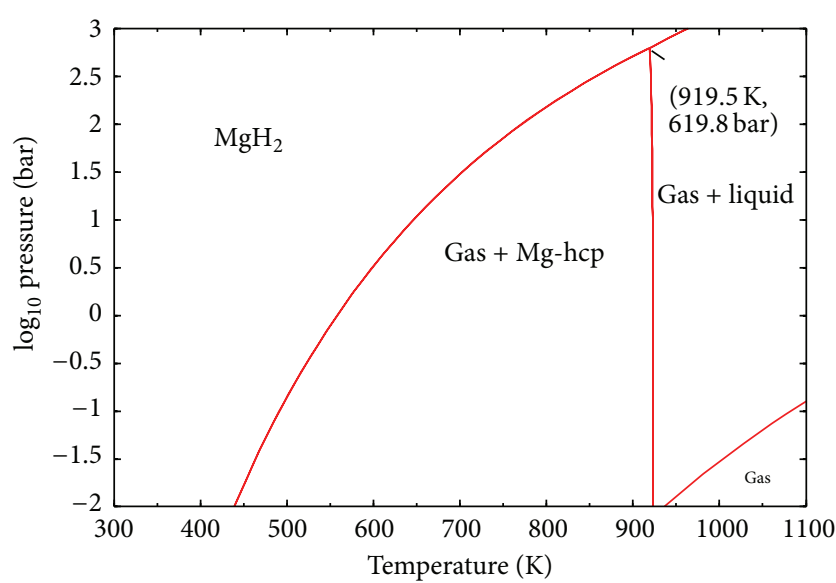

(b)

Figure 2: (a) The dissociation pressure of $\mathrm{MgH}_{2}$ calculated in this work compared to experimental data. (b) Predicted pressure-temperature diagram of $\mathrm{MgH}_{2}$.

agrees with the $1500 \pm 70 \mathrm{~K}$ estimated by Klostermeier and Franck [66].

Several measurements [59-64] on the $H$ solubility in liquid $\mathrm{Na}$ were found in the literature. The solubility values are very small. Hence to compare the experimental data with the present calculation a phase diagram of temperature versus $\log \mathrm{H} / \mathrm{Na}$ is plotted in Figure 6. This diagram shows the Na-rich side of the phase diagram from 371 to $900 \mathrm{~K}$. The solubility values are in general agreement with those from the literature. The cutoff point of the calculation in FactSage program is $1 \times 10^{-5}$. Therefore dotted lines have been used in the figure to extend parting lines of the phases.
Some of the experimental solubility data $[59,60,62]$ do not agree well with the present calculation. However, San-Martin and Manchester [56] noted that these measurements suffered from contamination due to the reaction of $\mathrm{Na}$ with glass walls. Therefore, during optimization only the other experimental data reported by Meacham et al. [63] and Vissers et al. [64] were given a higher weight in the present work.

The chemical potential diagram for the $\mathrm{H}-\mathrm{Na}$ system calculated in the present study is shown in Figure 7. The diagram shows reasonable agreement with the experimental data from the literature $[57,58,65,66]$. It can be seen from this diagram that, with increasing pressure, the dissociation 


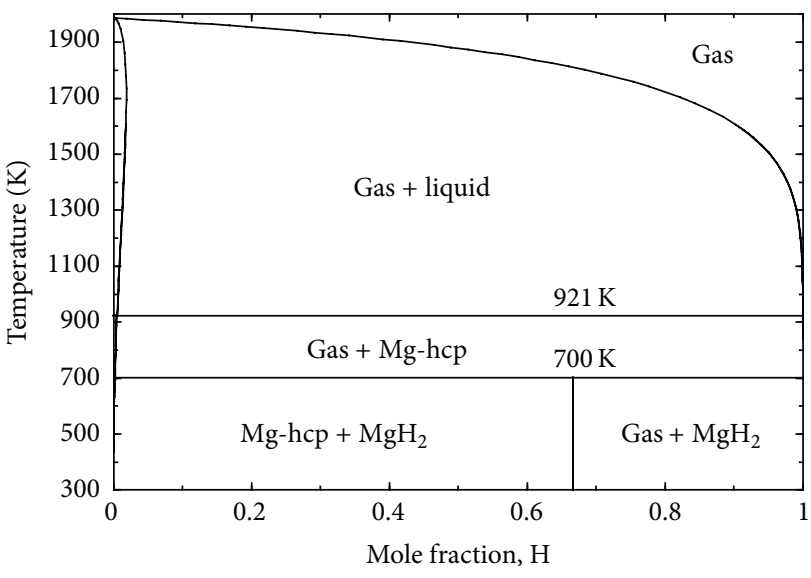

(a)

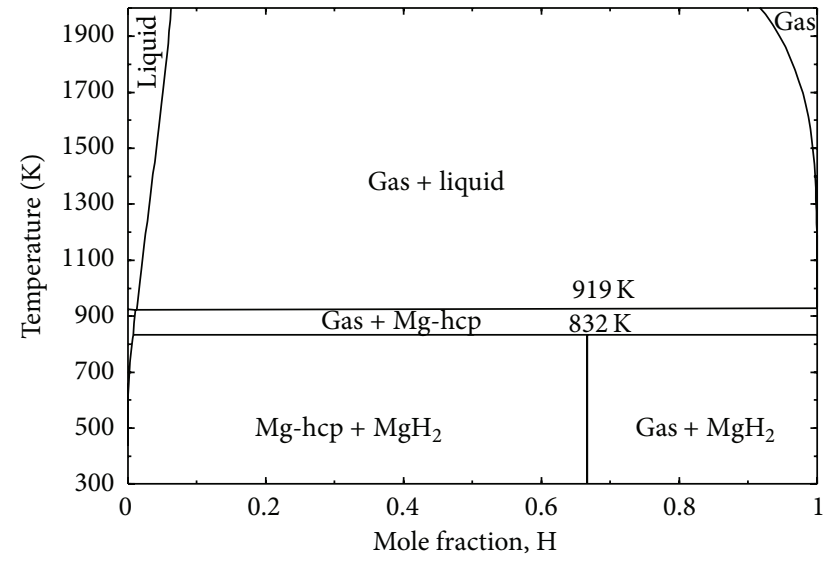

(b)

FIgURE 3: Calculated Mg-H phase diagram at (a) 30.48 bar and (b) 236 bar.

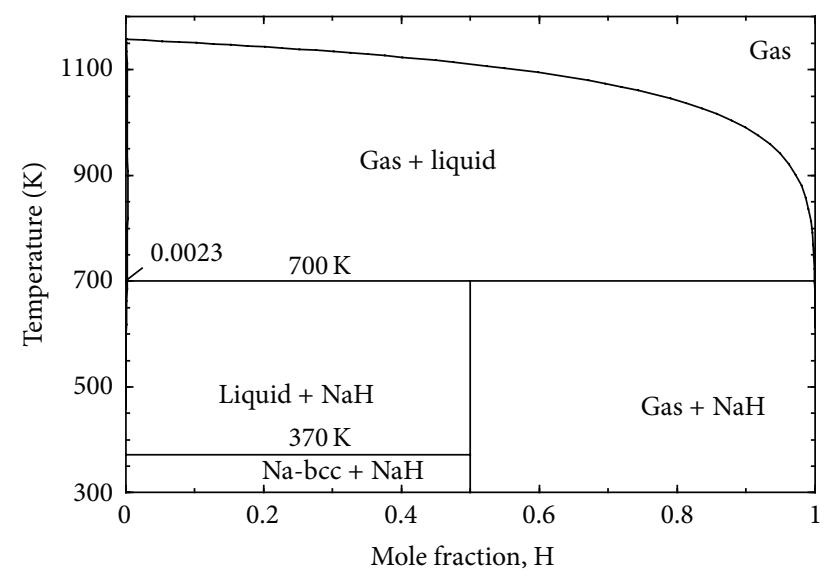

Figure 4: Calculated H-Na phase diagram at 1 bar.

temperature of $\mathrm{NaH}$ increases until $~ 114$ bar (at $911 \mathrm{~K}$ ) where melting of this compound occurs. After this point the slope of the curve decreases as no more $\mathrm{NaH}$ can dissolve in the liquid. This indicates the immiscibility of the two liquids. Similar observations were also reported by Qiu et al. [73].

The enthalpy of formation of the solid $\mathrm{NaH}$ has been determined as $-56.98 \mathrm{~kJ} / \mathrm{mol}$, which is consistent with the available experimental data as can be seen in Table 3. The calculated heat capacity of solid $\mathrm{NaH}$ with the available experimental data from Sayre and Beaver [79] is shown in Figure 8. In order to obtain reliable agreement with experimental data, the Gibbs energy of the solid $\mathrm{NaH}$ in the temperature range 0 $<T<298.15 \mathrm{~K}$ has been determined in this work. The Gibbs energy of this compound at higher temperatures $(298.15<$ $T<2000 \mathrm{~K})$ is taken from Qiu et al. [73].

4.3. $\mathrm{Mg}-\mathrm{Na}$ System. The calculated phase diagram of the Mg-Na system is presented in Figure 9. The thermodynamic model parameters obtained for the system are given in Table 1. The calculated phase diagram is in good agreement
TABLE 3: Enthalpy of formation of the $\mathrm{NaH}$ phase.

\begin{tabular}{lcc}
\hline $\begin{array}{l}\text { Enthalpy of formation } \\
\mathrm{kJ} / \mathrm{mole}\end{array}$ & $\begin{array}{c}\text { Temperature } \\
\mathrm{K}\end{array}$ & Reference \\
\hline-56.98 & 298 & This work \\
$-58.4 \pm 1.2$ & 623 & {$[57,78]$} \\
$-56.9 \pm 1.1$ & 298 & {$[76]$} \\
$-56.44 \pm 0.17$ & 298 & {$[75]$} \\
\hline
\end{tabular}

with the experimental data form the literature [81-85]. However, it differs a little from the calculation of Zhang et al. [85] at high temperature when the gas phase interacts with the liquid immiscibility gap. Zhang et al. [85] reported the gas $\rightarrow$ liquid 2 transformation at 97.01 at.\% Na which was found at 92.5 at.\% $\mathrm{Na}$ in the present work. Since there is no experimental data for this reaction the present prediction is acceptable. The composition and temperature of the invariant reactions in the $\mathrm{Mg}$-Na system calculated in the present work are compared with the experimental data from the literature, Table 4. Activities of $\mathrm{Mg}$ and $\mathrm{Na}$ in the liquid at $973 \mathrm{~K}$ are calculated and presented in Figure 10. The calculated Mg activity is in good agreement with the experimental measurements by Lantratov [82]. The Na activity shows deviation from that of Lantratov [82] in the liquid immiscibility gap. However, the experimental data showed unrealistic activity almost equal to unity and was not possible to obtain without deviating from the experimental phase diagram.

4.4. H-Mg-Na System. Calculated changes in enthalpy and entropy for reactions (2) and (3) and enthalpy and entropy of formation of $\mathrm{NaMgH}_{3}$ are given in Table 5 in comparison with experimental data from the literature. There is a good consistency between the calculated heat of formation of $\mathrm{NaMgH}_{3}$ in this work and the experimental values reported in the literature $[15,17,18,89]$ except for the DSC results published by Bouamrane et al. [13] which are higher. This can be attributed to the use of DSC for the measurement 


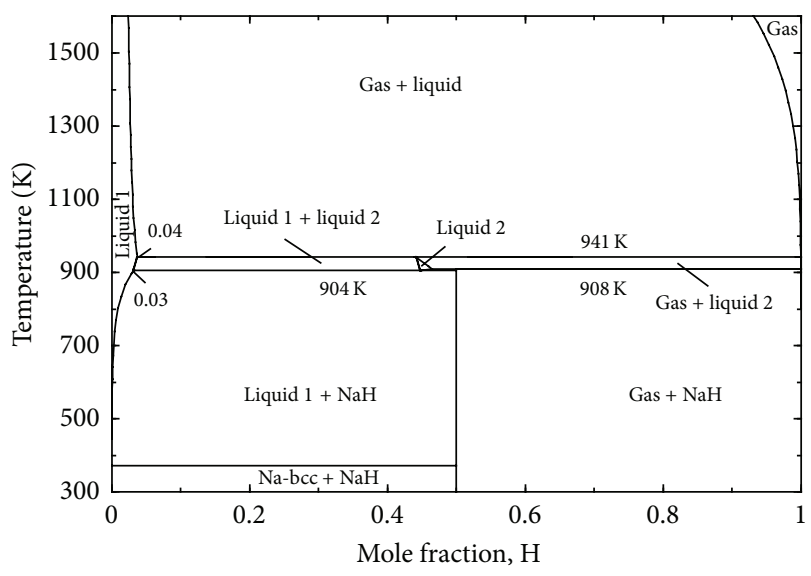

(a)

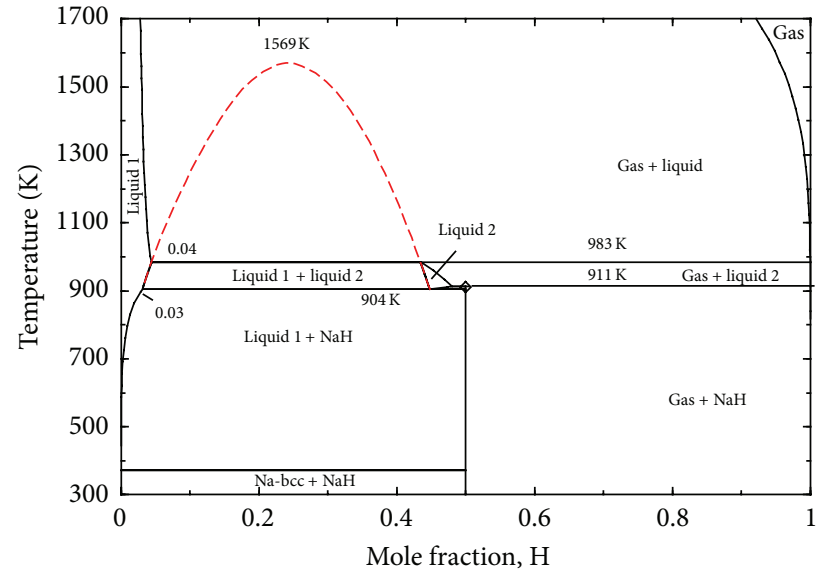

$\diamond$ Skuratov et al. (1976)

(b)

FIgURE 5: The Na-H phase diagram calculated at (a) 150 bar and (b) 200 bar showing the metastable immiscibility gap.

TABLE 4: Invariant reactions in the Mg-Na system.

\begin{tabular}{|c|c|c|c|c|c|}
\hline Reaction & Temp./K & & osition, $\mathrm{Na}$ & & Reference \\
\hline \multirow{2}{*}{ Gas $\rightarrow$ liquid 2} & 1153 & 92.5 & & & This study \\
\hline & 1157 & 97.016 & & & Modeling [86] \\
\hline \multirow{5}{*}{ Liquid $1 \rightarrow$ hcp- $(\mathrm{Mg})+$ liquid 2} & 910 & 2.25 & 0.11 & 93.21 & This study \\
\hline & 910 & 2.10 & 0.033 & 92.70 & Modeling [86] \\
\hline & 911 & $2.0 \pm 0.1$ & & & Experiment [81] \\
\hline & 911 & 2.1 & & 98.6 & Experiment [83] \\
\hline & 910 & 1.6 & & 92.7 & Experiment [82] \\
\hline \multirow{4}{*}{ Liquid $2 \rightarrow$ hcp-(Mg) + bcc- $(\mathrm{Na})$} & 371 & 99.97 & $1.0 \times 10^{-3}$ & 100 & This study \\
\hline & 371 & 99.98 & $4.15 \times 10^{-4}$ & 100.00 & Modeling [86] \\
\hline & 371 & & & & Experiment [81] \\
\hline & 371 & & & & Experiment [82] \\
\hline
\end{tabular}

of thermodynamic properties of the hydrides instead of PCI method which is more accurate due to its reliance on the change in volume. The calculated enthalpy and entropy of reactions (2) and (3) are in very good agreement with the values reported by Sheppard et al. [88]. Agreement is also shown between the calculated enthalpy of reaction (2) with Ikeda et al. [18] as well as between the calculated entropy of reaction (3) and Komiya et al. [17]. As discussed in Section 2.4, all the other differences are related to the PCIs quality and poor kinetics in $[15,17,27]$.

The calculated PCI profiles at various temperatures are presented in Figure 11 in comparison with the experimental data reported by Sheppard et al. [88]. It has been reported by these authors [88] that the samples used for the PCI measurements were composed of 84.3 wt. $\% \mathrm{NaMgH}_{3}, 4.7$ wt.\% $\mathrm{NaH}$, and $11.0 \mathrm{wt} . \% \mathrm{MgO}$. In the present work, the hydrogen wt.\% desorbed from the samples has been recalculated to consider only the $\mathrm{NaMgH}_{3}$ content assuming no reaction between $\mathrm{H}_{2}, \mathrm{MgO}$, and $\mathrm{NaH}$. The hydrogen content of the samples was calculated by subtracting the hydrogen desorbed from the total hydrogen content before desorption (6 wt.\%). These results (Figure 11) show that the model used to describe the $\mathrm{NaMgH}_{3}$ reproduces the equilibrium pressures at different temperatures. The calculated PCI at $671.4 \mathrm{~K}$ in comparison with the experimental one shows that there is agreement between the theoretical and the measured hydrogen content of the first sample. It can be seen that the amount of hydrogen desorbed from the samples is decreasing after each experiment probably because of incomplete hydriding or dehydriding reactions and very sluggish kinetics.

The calculated pressure-temperature diagram of $\mathrm{NaMgH}_{3}$ is presented in Figure 12 in relation to experimental data from the literature. There is good agreement between the calculated and the experimental data except for the PCI results obtained by Pottmaier et al. [27] at $650 \mathrm{~K}$. This deviation was expected because of the poor quality of the PCIs reported by Pottmaier et al. [27] due to very low kinetics especially for low temperature experiments as discussed before. Figure 12 indicates that $\mathrm{NaMgH}_{3}$ is stable up to higher temperatures when the pressure is increased (up 
TABLE 5: Thermodynamic properties of $\mathrm{NaMgH}_{3}$ decomposition from PCI and DSC experiments.

\begin{tabular}{|c|c|c|c|c|c|}
\hline \multicolumn{2}{|c|}{ Reaction (2) } & \multicolumn{2}{|c|}{ Reaction (3) } & \multirow{2}{*}{$\Delta_{f} H^{0}\left(\mathrm{NaMgH}_{3}\right)(\mathrm{kJ} / \mathrm{mol})$} & \multirow{2}{*}{ Reference } \\
\hline$\Delta H\left(\mathrm{~kJ} / \mathrm{molH}_{2}\right)$ & $\Delta S\left(\mathrm{~J} / \mathrm{molH}_{2} \mathrm{~K}\right)$ & $\Delta H\left(\mathrm{~kJ} / \mathrm{molH}_{2}\right)$ & $\Delta S\left(\mathrm{~J} / \mathrm{molH}_{2} \cdot \mathrm{K}\right)$ & & \\
\hline 85.45 & 127.2 & 114 & 154.2 & -142.44 & This work \\
\hline- & - & - & - & $-231^{* *}$ & {$[13]$} \\
\hline $88 \pm 0.9$ & - & - & - & $-145^{*}$ & {$[18]$} \\
\hline $93.9 \pm 6$ & $116.2 \pm 9$ & $102.2 \pm 4$ & $125.9 \pm 6$ & $-145^{*}$ & [15] \\
\hline $94 \pm 15$ & $140 \pm 22$ & $116 \pm 2$ & $165 \pm 3$ & $-152^{*}$ & [17] \\
\hline 92 & 123 & - & - & - & [27] \\
\hline $86.6 \pm 1$ & $132.2 \pm 1.3$ & 117 & 168.2 & $-145.1^{*}$ & {$[88]$} \\
\hline
\end{tabular}

${ }^{*}$ The values are (re)calculated in this work using $\Delta H$ values reported in the literature; ${ }^{* *}$ data obtained by DSC measurements.

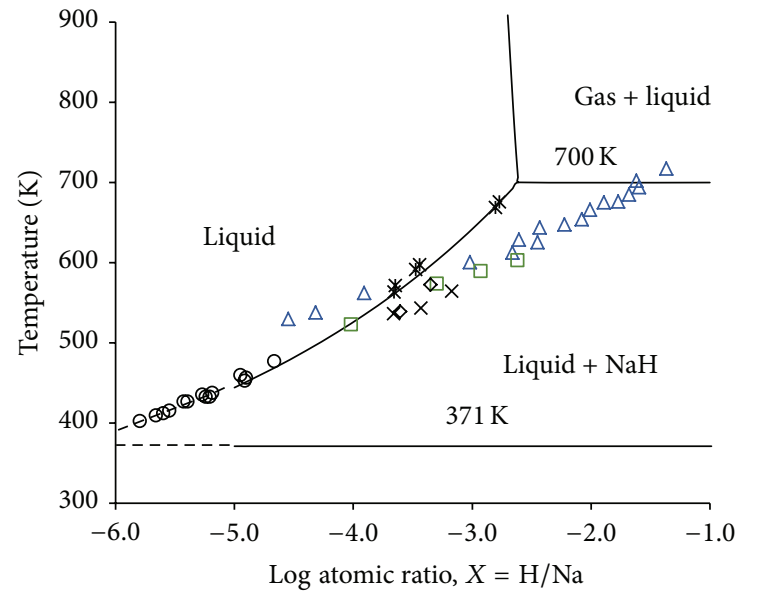

$\triangle$ Williams et al. (1957)
$\square$ Addison et al. (1965)
$\diamond$ McClure and Halsey (1965)
$\times$ Newcombe and Thompson (1968)
$*$ Meacham et al. (1970)
$\circ$ Vissers et al. (1974)

FIgURE 6: Calculated hydrogen solubility in the liquid Na system at 1-bar pressure in comparison to the experimental data in the literature [59-64].

to $\sim 900 \mathrm{~K}$ at $\sim 100$ bar). However, the stability region for $\mathrm{NaH}$ is relatively small. It can be seen in Figure 12 that the two-step decomposition of $\mathrm{NaMgH}_{3}$ through reactions (2) and (3) transforms into a single step decomposition $\left(\mathrm{NaMgH}_{3} \rightarrow\right.$ liquid + hcp- $(\mathrm{Mg})+$ gas) from $825.3 \mathrm{~K}$ and 25.8 bar.

Pottmaier et al. [27] observed an important decrease in hydrogen capacity of $\mathrm{NaMgH}_{3}$ after 15 cycles of hydrogenation/dehydrogenation and observed at the end of the measurements that metallic $\mathrm{Na}$ segregated into isolated blocks which, according to these authors [27], caused this loss in capacity. Sheppard et al. [88] reported a dramatic reduction in the rehydrogenation reaction kinetics of the products $(\mathrm{Na}$ (l) and hcp-(Mg)) to form $\mathrm{NaMgH}_{3}$ and supported Pottmaier et al. [27] conclusion. This suggests that avoiding liquid $\mathrm{Na}$ during the decomposition of $\mathrm{NaMgH}_{3}$ significantly improves the kinetics and prevents capacity degradation. According to the present calculation the best working temperatures and

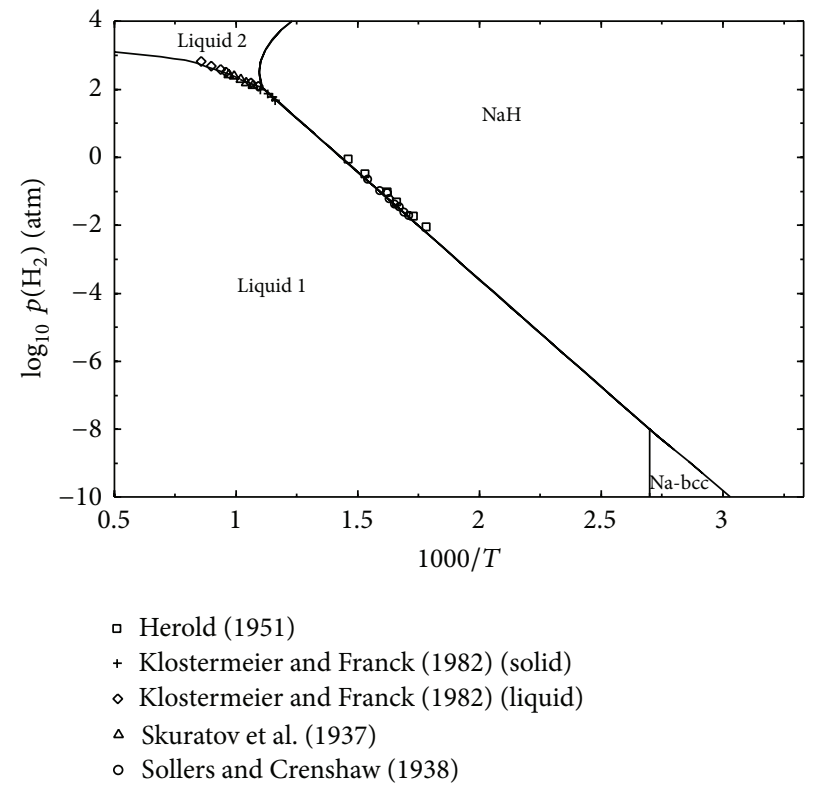

FIGURE 7: Calculated dissociation pressure of $\mathrm{NaH}$ in comparison with the experimental data from the literature.

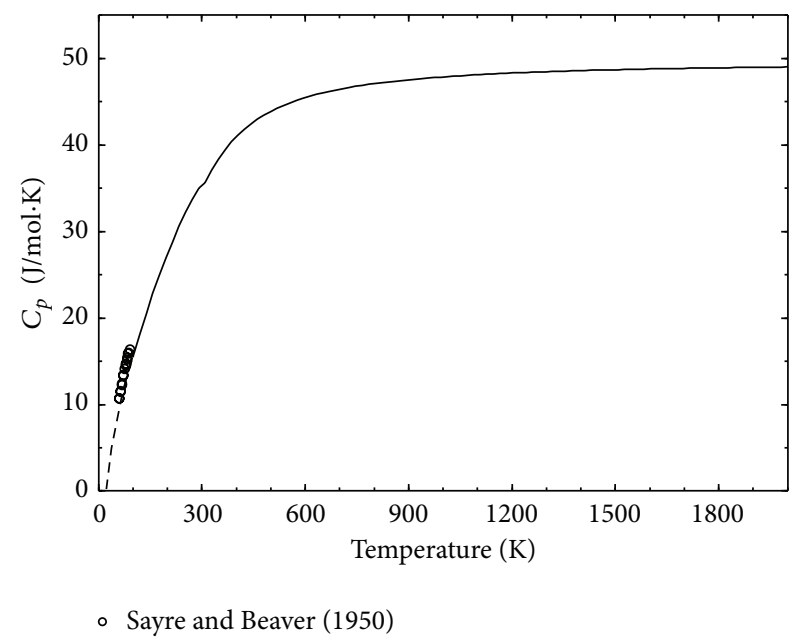

FIGURE 8: Calculated heat capacity $c_{p}$ of $\mathrm{NaH}$ in comparison with experimental data [79]. 


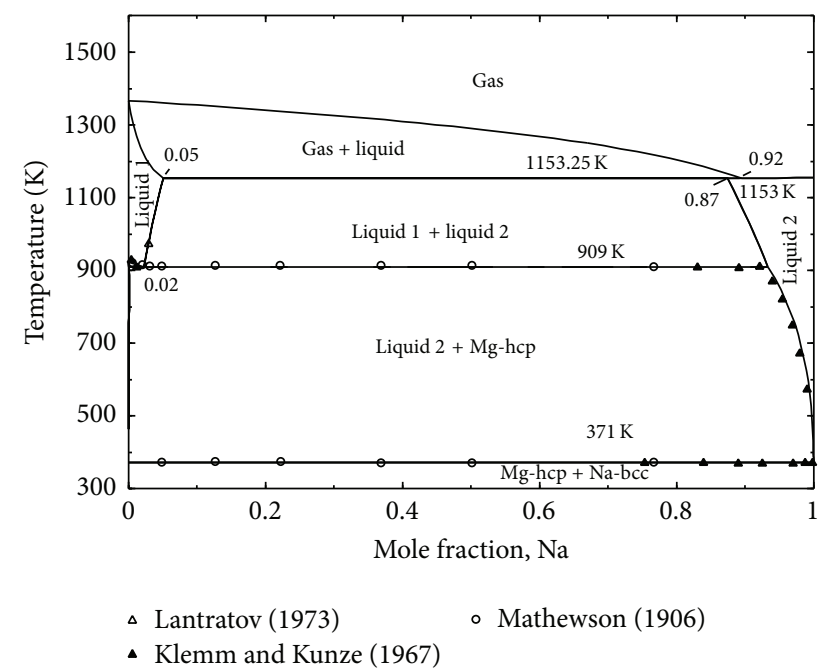

Figure 9: The calculated phase diagram for $\mathrm{Mg}-\mathrm{Na}$ system in comparison with the experimental Data.

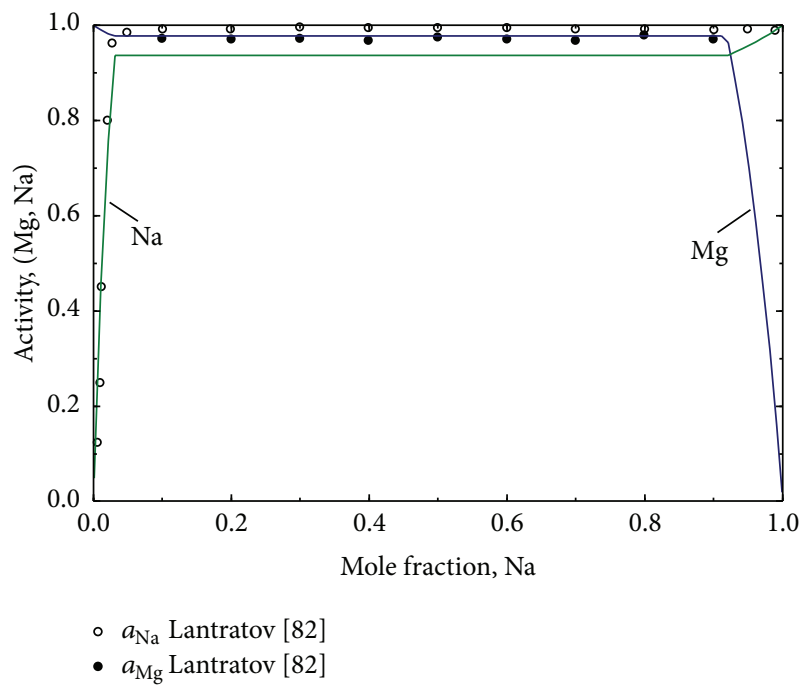

FIgURE 10: The calculated activities of liquid $\mathrm{Na}$ and liquid $\mathrm{Mg}$ at $973 \mathrm{~K}$ in comparison with the experimental data [82].

pressures for $\mathrm{NaMgH}_{3}$ are shown as the shaded region in Figure 12 as this region avoids the liquid formation.

It has been shown by Wang et al. [19] that the addition of $10 \mathrm{wt} . \%$ of $\mathrm{NaH}$ greatly improved the hydrogen storage properties and the hydrolysis properties of $\mathrm{MgH}_{2}$ due to the formation of $\mathrm{NaMgH}_{3}$. As mentioned earlier, the perovskite structure allows fast hydrogen mobility and gives $\mathrm{NaMgH}_{3}$ the catalytic role necessary for hydrogen storage capacity improvement of $\mathrm{MgH}_{2}$. In Figure 13, the calculated vertical section of $\mathrm{Mg}-\mathrm{Na}-\mathrm{H}$ system along the composition line $\mathrm{MgH}_{2}-\mathrm{NaH}$ at 1 bar and 100 bar is presented. Figure 13 shows that when 10 wt. $\%$ of $\mathrm{NaH}$ is added to $\mathrm{MgH}_{2}, \mathrm{NaMgH}_{3}$ forms. Also, all phase transformations with temperature at 1 bar and at 100 bar can be inferred from this figure. Since this figure does not provide the relative amounts of each phase,

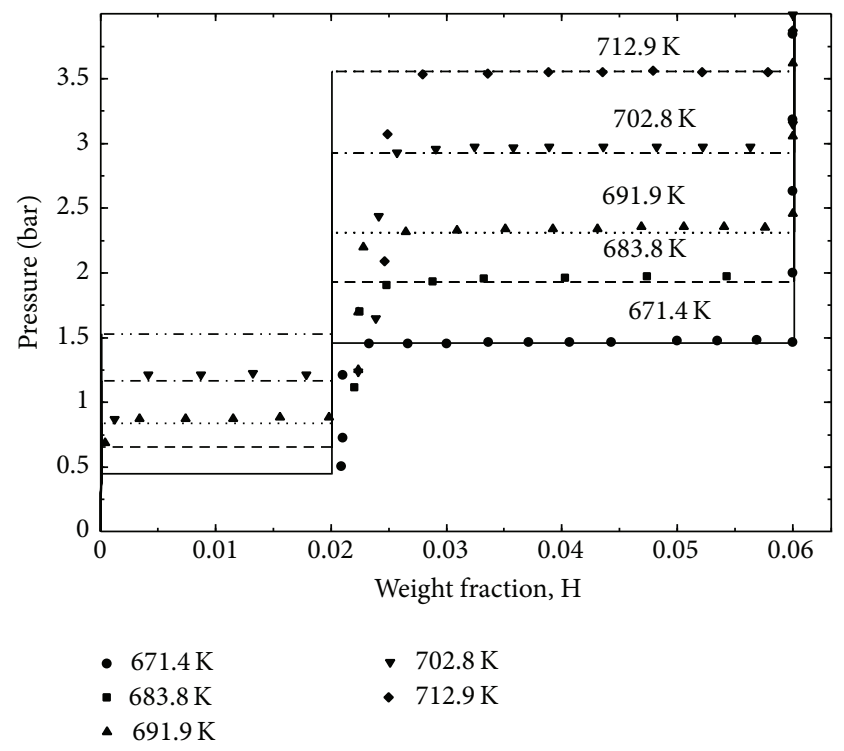

FIgURE 11: Calculated PCIs for $\mathrm{NaMgH}_{3}$ at various temperatures compared to experimental data reported by Sheppard et al. [88].

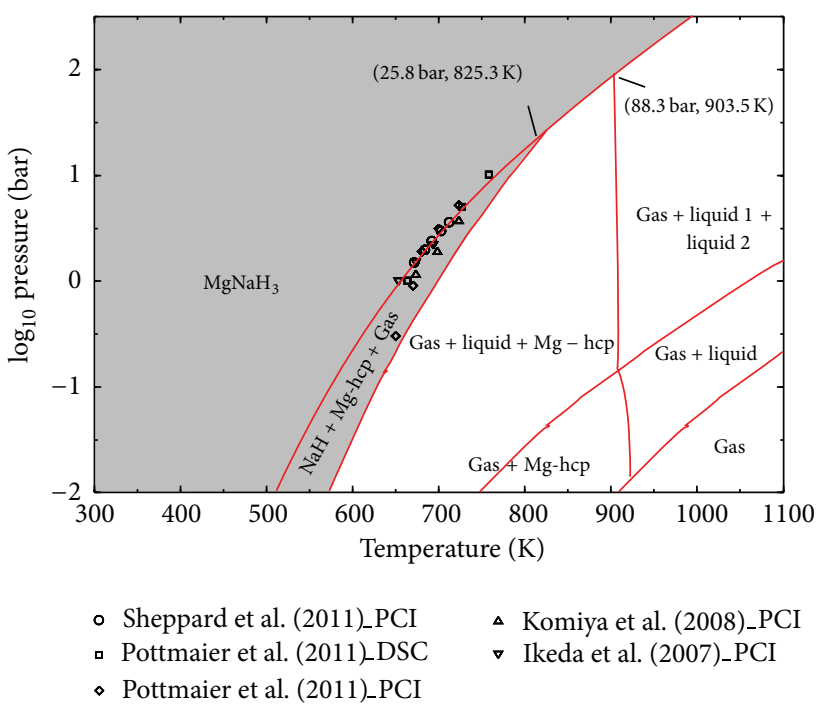

FIGURE 12: Calculated pressure-temperature equilibrium diagram for $\mathrm{NaMgH}_{3}$ in comparison with experimental data from the literature.

phase assemblage diagrams are calculated as will be discussed below.

Calculated PCI curves for the $\mathrm{MgH}_{2}+10$ wt. $\% \mathrm{NaH}$ mixtures at 623 and $673 \mathrm{~K}$ are shown in Figure 14(a) in comparison with the results published by Wang et al. [19]. The hydrogen content of the samples in [19] has been recalculated assuming that the initial samples' hydrogen capacity is $7.3 \mathrm{wt}$.\% based on the chemical formulae assuming stoichiometric amounts. At $673 \mathrm{~K}$, three plateau pressures are shown in the calculated PCI curve (see arrows A, B, and $\mathrm{C}$ in Figure 14). The higher plateau (A) corresponds to the decomposition of $\mathrm{MgH}_{2}$; the second (B) and the third 


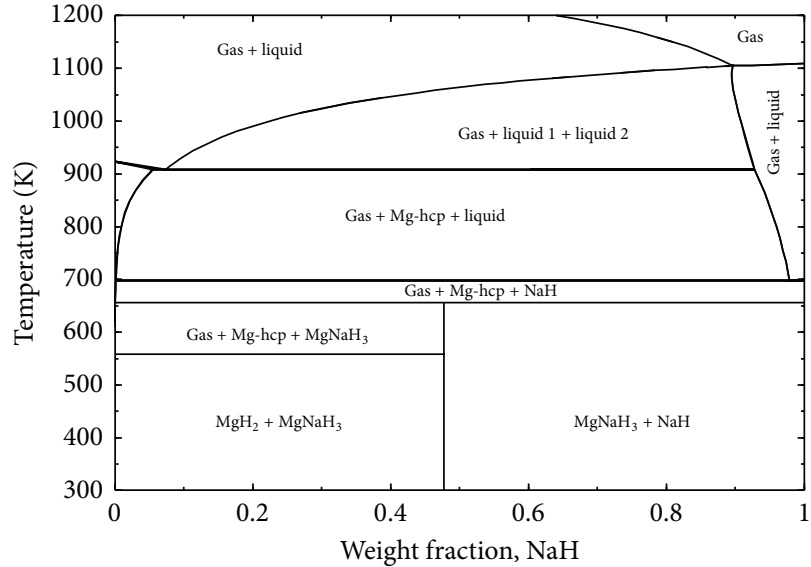

(a)

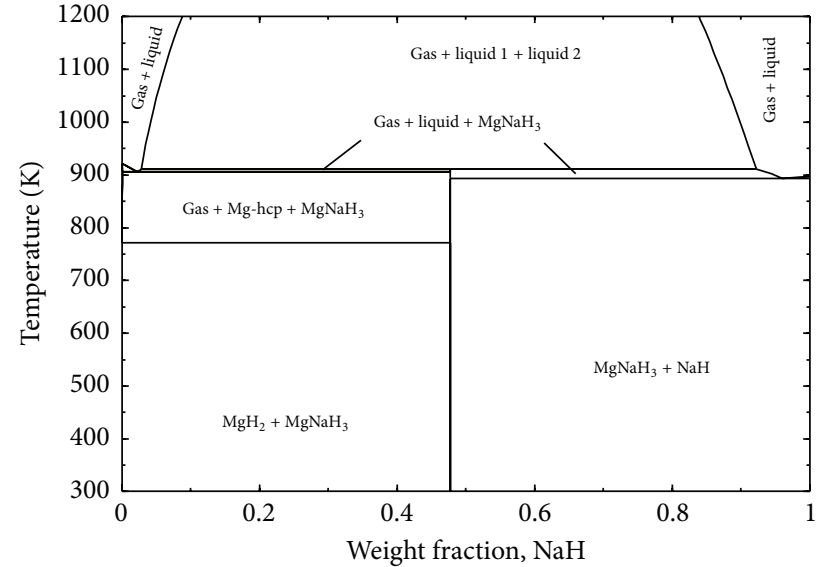

(b)

FIGURE 13: Calculated vertical section of $\mathrm{Mg}-\mathrm{Na}-\mathrm{H}$ system along the composition line $\mathrm{MgH}_{2}-\mathrm{NaH}$ at (a) 1 bar and (b) 100 bar.

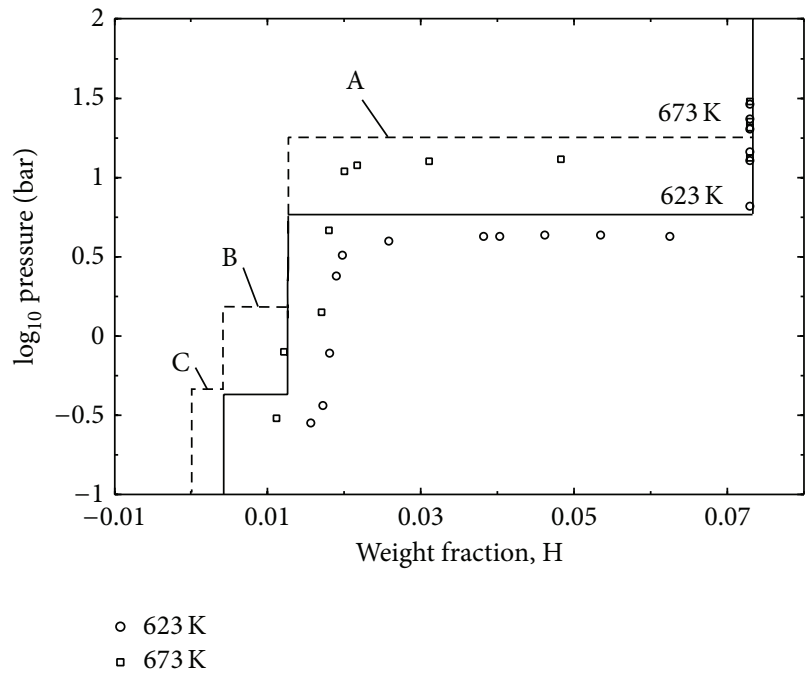

(a)

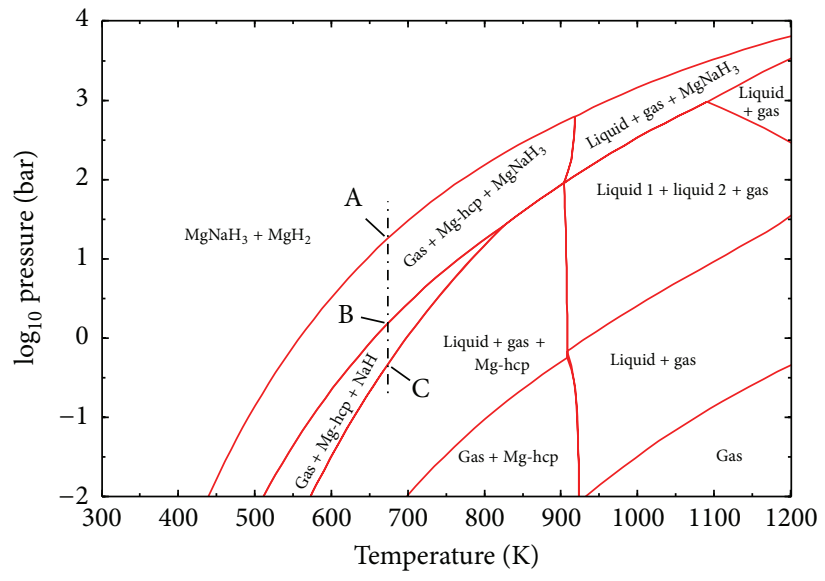

(b)

Figure 14: (a) Calculated P-C isotherm for $\mathrm{MgH}_{2}+10 \mathrm{wt} . \% \mathrm{NaH}$ at 623 and $673 \mathrm{~K}$ compared to experimental data [19]. (b) Calculated pressure-temperature diagram for $\mathrm{MgH}_{2}+10$ wt. $\% \mathrm{NaH}$.

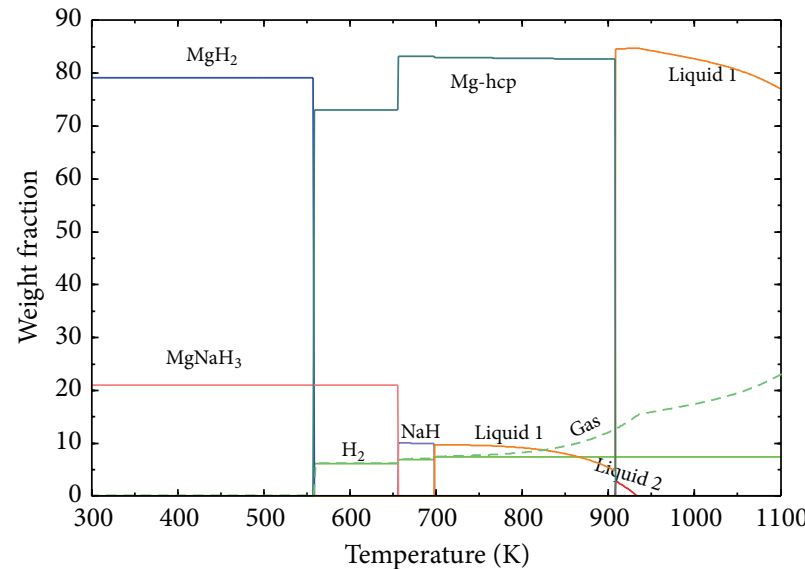

(a)

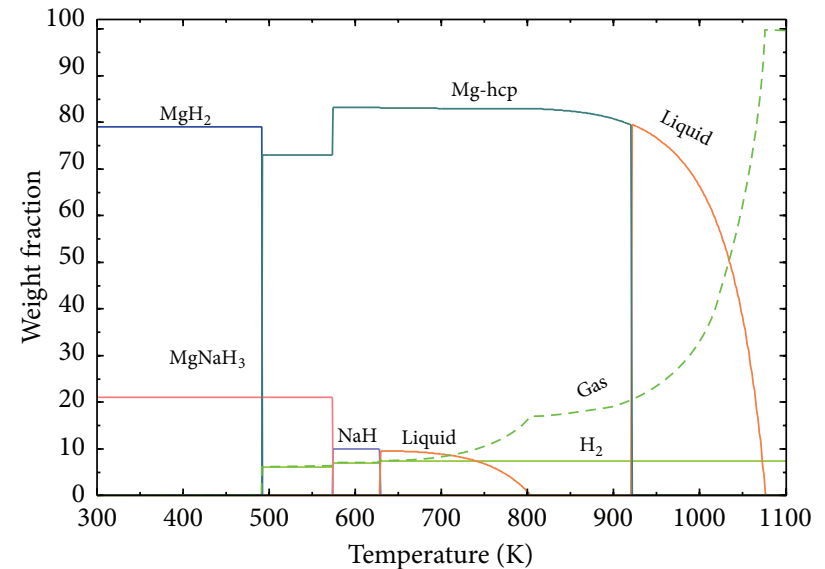

(b)

Figure 15: Calculated reaction path for $\mathrm{MgH}_{2}+10 \mathrm{wt} . \% \mathrm{NaH}$ at (a) 1 bar and (b) 0.1 bar. 
(C) plateaus correspond to the decomposition of $\mathrm{NaMgH}_{3}$ through reactions (2) and (3), respectively. At $623 \mathrm{~K}$, only the first two plateaus are observed and the formation of liquid $\mathrm{Na}$ through reaction (3) is avoided. The last plateau ( $\mathrm{C}$ in the PCI curve at $673 \mathrm{~K}$ ) and the two last plateaus (in the PCI curve at $623 \mathrm{~K}$ ) could not be observed by Wang et al. [19] and their reported plateau pressures are slightly lower than the current calculations. No information has been given by Wang et al. [19] about their PCI measurements conditions, but very few data points are shown in the published curves. It has been pointed out by Wang et al. [19] that their testing temperatures for kinetic measurements have been chosen below $623 \mathrm{~K}$ to avoid the decomposition of $\mathrm{NaMgH}_{3}$, but, according to the present calculations, $\mathrm{NaMgH}_{3}$ decomposes at this temperature through reaction (2) and only reaction (3) is avoided during desorption in the pressure range of measurement.

The calculated pressure-temperature diagram for the $\mathrm{MgH}_{2}+10$ wt.\% NaH composition is shown in Figure 14(b). The plateau pressures at $673 \mathrm{~K}$ shown in Figure 14(a) (A, $\mathrm{B}$, and C) are also indicated by arrows in Figure 14(b). It can be seen that Figure 14(b) is a superimposition of Figure 2(b) (pressure-temperature diagram for $\mathrm{MgH}_{2}$ ) and Figure 12 (pressure-temperature diagram for $\mathrm{NaMgH}_{3}$ ) for temperatures below $\sim 900 \mathrm{~K}$. This result suggests that the thermodynamic properties of $\mathrm{MgH}_{2}$ and $\mathrm{NaMgH}_{3}$ are not affected when mixing $\mathrm{MgH}_{2}$ with $\mathrm{NaH}$. Only the amount of hydrogen desorbed from the mixture (the plateaus width) at each step changes with the amount of $\mathrm{NaH}$ added. In other words, from a thermodynamic point of view, addition of $\mathrm{NaH}$ to $\mathrm{MgH}_{2}$ does not improve the hydrogen storage properties of $\mathrm{MgH}_{2}$. On the contrary, the absorption/desorption kinetics is significantly improved as reported in the literature. For this purpose as well, the full potential of the catalytic role of $\mathrm{NaMgH}_{3}$ can only be obtained if the processing conditions are set as shown by the shaded region in Figure 12.

The decomposition temperature and the amount of released hydrogen for any compositions of the $\mathrm{H}-\mathrm{Mg}-\mathrm{Na}$ system can be obtained at any pressure using the current database. The calculations for three different pressures $(1,0.1$, and $1 \times 10^{-4}$ bar) are discussed below.

The calculated reaction path of the $\mathrm{MgH}_{2}+10 \mathrm{wt} . \% \mathrm{NaH}$ at 1 and 0.1 bar is given in Figures 15(a) and 15(b), respectively. The reaction path at 1 bar is as follows: $\mathrm{MgH}_{2}$ decomposes first at $557.8 \mathrm{~K}$ to hcp-(Mg) and 6 wt. $\% \mathrm{H}_{2}$ gas. $\mathrm{NaMgH}_{3}$ decomposes second at $656 \mathrm{~K}$ to $\mathrm{NaH}$, hcp-(Mg), and an additional 0.9 wt. $\% \mathrm{H}_{2}$ gas. At $697 \mathrm{~K}, \mathrm{NaH}$ decomposes to liquid and an additional $0.4 \mathrm{wt} . \% \mathrm{H}_{2}$ gas. Slow decrease in the amount of liquid phase from $700 \mathrm{~K}$ is accompanied with the evaporation of $\mathrm{Na}$. The total amount of gas phase is presented in dashed line. A second liquid phase appears at the melting point of magnesium and disappears at $933 \mathrm{~K}$ where $\mathrm{Mg}$ starts to evaporate with decreasing the amount of the liquid phase. At $0.1 \mathrm{bar}$, as expected, the decomposition temperatures of the hydrides, the evaporation points of $\mathrm{Na}$ and $\mathrm{Mg}$, and the sublimation point of $\mathrm{Mg}$ are lower. $\mathrm{MgH}_{2}$ decomposes at $491 \mathrm{~K}$ to hcp-(Mg) and 6 wt. $\% \mathrm{H}_{2}$ gas and $\mathrm{NaMgH}_{3}$ at $573 \mathrm{~K}$ liberating an additional $0.9 \mathrm{wt} . \% \mathrm{H}_{2}$ gas. $\mathrm{NaH}$ decomposes at $628 \mathrm{~K}$ to liquid and an additional $0.4 \mathrm{wt} . \% \mathrm{H}_{2}$ gas. According to the present calculation, at a pressure of $1 \times 10^{-4}$ bar, $\mathrm{MgH}_{2}$ decomposes at $366 \mathrm{~K}, \mathrm{NaMgH}_{3}$ at $418 \mathrm{~K}$, and $\mathrm{NaH}$ at $486 \mathrm{~K}$. It is concluded in this work that $\mathrm{MgH}_{2}$ will decompose at temperatures lower than $373 \mathrm{~K}$ with good kinetics at low pressures if it is mixed with a small amount of $\mathrm{NaMgH}_{3}$.

\section{Conclusion}

A self-consistent thermodynamic database has been constructed to describe the $\mathrm{H}-\mathrm{Mg}-\mathrm{Na}$ system. Thermodynamic modeling of the constituent binary systems, $\mathrm{H}-\mathrm{Mg}, \mathrm{H}-\mathrm{Na}$, and $\mathrm{Mg}-\mathrm{Na}$, has been carried out. The modified quasichemical model is used to describe the liquid phase. Thermodynamic calculations of various phase diagrams and thermodynamic properties are compared with the experimental data and found to be in good agreement. The binary thermodynamic parameters of the liquid phases were interpolated using the asymmetric Kohler-Toop technique. The solid solution phases, hcp-Mg and bcc-( $\mathrm{Na})$, are described by twosublattice models as $(\mathrm{Mg}, \mathrm{Na})_{2}(\mathrm{H}, \mathrm{Va})_{1}$ and $(\mathrm{Na}, \mathrm{Mg})_{1}(\mathrm{H}, \mathrm{Va})_{3}$. The constructed database is used to predict the PCIs and the pressure-temperature diagram of the $\mathrm{MgH}_{2}+10 \mathrm{wt} . \%$ $\mathrm{NaH}$ mixture. The calculations provide more insight into the reactions when compared to experimental data from the literature. The reaction path of the $\mathrm{MgH}_{2}+10 \mathrm{wt} . \% \mathrm{NaH}$ mixture is predicted at different pressures. In this study, it is demonstrated that $\mathrm{H}-\mathrm{Mg}-\mathrm{Na}$ system does not satisfy all the DOE requirements for onboard hydrogen storage applications (desorption temperature $<373 \mathrm{~K}$, at atmospheric pressure) but still is very good candidate for high temperature applications. According to this work, at 1 bar, $\mathrm{NaMgH}_{3}$ decomposes at $656 \mathrm{~K}$ to $\mathrm{NaH}$ and hcp-(Mg) liberating $6 \mathrm{wt} . \%$ of hydrogen gas. The present database is used to find the best working temperatures and pressures of $\mathrm{NaMgH}_{3}$ to avoid its full decomposition and benefit from its full catalytic role when mixed with $\mathrm{MgH}_{2}$. At pressures of $1,0.1$, and $10^{-4} \mathrm{bar}$, the limiting working temperature should be 697,628 , and $486 \mathrm{~K}$, respectively. It is also found that $\mathrm{MgH}_{2}$ decomposes at $366 \mathrm{~K}$ at a pressure of $10^{-4}$ bar. The present database can be used for further thermodynamic assessments of higher order systems.

\section{Conflict of Interests}

The authors declare that there is no conflict of interests regarding the publication of this paper.

\section{Acknowledgment}

The authors acknowledge NSERC for financial support of the project through NSERC Hydrogen Canada Network $\left(\mathrm{H}_{2} \mathrm{Can}\right)$.

\section{References}

[1] R. J. Press, K. S. V. Santhanam, M. J. Miri, A. V. Bailey, and G. A. Takacs, Introduction to Hydrogen Technology, 2009. 
[2] I. P. Jain, P. Jain, and A. Jain, "Novel hydrogen storage materials: a review of lightweight complex hydridespuye," Journal of Alloys and Compounds, vol. 503, no. 2, pp. 303-339, 2010.

[3] S.-I. Orimo, Y. Nakamori, J. R. Eliseo, A. Züttel, and C. M. Jensen, "Complex hydrides for hydrogen storage," Chemical Reviews, vol. 107, no. 10, pp. 4111-4132, 2007.

[4] B. Sakintuna, F. Lamari-Darkrim, and M. Hirscher, "Metal hydride materials for solid hydrogen storage: a review," International Journal of Hydrogen Energy, vol. 32, no. 9, pp. 1121-1140, 2007.

[5] P. Chen and M. Zhu, "Recent progress in hydrogen storage," Materials Today, vol. 11, no. 12, pp. 36-43, 2008.

[6] L. George and S. K. Saxena, "Structural stability of metal hydrides, alanates and borohydrides of alkali and alkali-earth elements: a review," International Journal of Hydrogen Energy, vol. 35, no. 11, pp. 5454-5470, 2010.

[7] G. Barkhordarian, T. Klassen, M. Dornheim, and R. Bormann, "Unexpected kinetic effect of $\mathrm{MgB}_{2}$ in reactive hydride composites containing complex borohydrides," Journal of Alloys and Compounds, vol. 440, no. 1-2, pp. L18-L21, 2007.

[8] M. Dornheim, S. Doppiu, G. Barkhordarian et al., "Hydrogen storage in magnesium-based hydrides and hydride composites," Scripta Materialia, vol. 56, no. 10, pp. 841-846, 2007.

[9] A. Zaluska, L. Zaluski, and J. O. Ström-Olsen, "Nanocrystalline magnesium for hydrogen storage," Journal of Alloys and Compounds, vol. 288, no. 1-2, pp. 217-225, 1999.

[10] J. J. Vajo, S. L. Skeith, and F. Mertens, "Reversible storage of hydrogen in destabilized $\mathrm{LiBH}_{4}$," The Journal of Physical Chemistry B, vol. 109, no. 9, pp. 3719-3722, 2005.

[11] Y. Bouhadda, N. Fenineche, and Y. Boudouma, "Hydrogen storage: lattice dynamics of orthorhombic $\mathrm{NaMgH}_{3}$, Physica B: Condensed Matter, vol. 406, no. 4, pp. 1000-1003, 2011.

[12] D. Pottmaier, E. R. Pinatel, J. G. Vitillo et al., "Structure and thermodynamic properties of the $\mathrm{NaMgH} 3$ perovskite: a comprehensive study," Chemistry of Materials, vol. 23, no. 9, pp. 2317-2326, 2011.

[13] A. Bouamrane, C. de Brauer, J.-P. Soulié, J. M. Létoffé, and J. P. Bastide, "Standard enthalpies of formation of sodiummagnesium hydride and hydridofluorides $\mathrm{NaMgH}$, NaMgH2F and NaMgF2H," Thermochimica Acta, vol. 326, no. 1-2, pp. 3741, 1999.

[14] E. Rönnebro, D. Noréus, K. Kadir, A. Reiser, and B. Bogdanovic, "Investigation of the perovskite related structures of $\mathrm{NaMgH}_{3}$, $\mathrm{NaMgF}_{3}$ and $\mathrm{Na}_{3} \mathrm{AlH}_{6}$," Journal of Alloys and Compounds, vol. 299, no. 1-2, pp. 101-106, 2000.

[15] K. Ikeda, S. Kato, Y. Shinzato et al., "Thermodynamical stability and electronic structure of a perovskite-type hydride, $\mathrm{NaMgH}_{3}$," Journal of Alloys and Compounds, vol. 446-447, pp. 162-165, 2007.

[16] H. Wu, W. Zhou, T. J. Udovic, J. J. Rush, and T. Yildirim, "Crystal chemistry of perovskite-type hydride $\mathrm{NaMgH}$ : implications for hydrogen storage," Chemistry of Materials, vol. 20, no. 6, pp. 2335-2342, 2008.

[17] K. Komiya, N. Morisaku, R. Rong et al., "Synthesis and decomposition of perovskite-type hydrides, $\mathrm{MMgH}_{3}(\mathrm{M}=\mathrm{Na}, \mathrm{K}, \mathrm{Rb})$," Journal of Alloys and Compounds, vol. 453, no. 1-2, pp. 157-160, 2008.

[18] K. Ikeda, Y. Kogure, Y. Nakamori, and S. Orimo, "Reversible hydriding and dehydriding reactions of perovskite-type hydride NaMgH3," Scripta Materialia, vol. 53, no. 3, pp. 319-322, 2005.
[19] H. Wang, J. Zhang, J. W. Liu, L. Z. Ouyang, and M. Zhu, "Catalysis and hydrolysis properties of perovskite hydride $\mathrm{NaMgH} 3$," Journal of Alloys and Compounds, vol. 580, no. 1, pp. S197-S201, 2013.

[20] D. T. Shanes, R. L. Corey, R. C. Bowman Jr. et al., "NMR studies of the hydrogen storage compound $\mathrm{NaMgH}_{3}$," The Journal of Physical Chemistry C, vol. 113, no. 42, pp. 18414-18419, 2009.

[21] O. Dolotko, N. Paulson, and V. K. Pecharsky, "Thermochemical transformations in $2 \mathrm{MNH}_{2}-3 \mathrm{MgH}_{2}$ systems $(M=\mathrm{Li}$ or $\mathrm{Na})$," International Journal of Hydrogen Energy, vol. 35, no. 10, pp. 4562-4568, 2010.

[22] D. A. Sheppard, M. Paskevicius, and C. E. Buckley, "Hydrogen desorption from the $\mathrm{NaNH}_{2}-\mathrm{MgH}_{2}$ system," Journal of Physical Chemistry C, vol. 115, no. 16, pp. 8407-8413, 2011.

[23] S. Sartori, X. Qi, N. Eigen et al., "A search for new Mg- and Kcontaining alanates for hydrogen storage," International Journal of Hydrogen Energy, vol. 34, no. 10, pp. 4582-4586, 2009.

[24] X. Tang, S. M. Opalka, B. L. Laube, F.-J. Wu, J. R. Strickler, and D. L. Anton, "Hydrogen storage properties of Na-Li-Mg-Al-H complex hydrides," Journal of Alloys and Compounds, vol. 446447, pp. 228-231, 2007.

[25] R. Zidan, K. L. Shanahan, D. L. Anton, A. R. Jurgensen, and J. Pittman, "Development and characterization of novel complex hydrides synthesized via Molten state processing," in Proceedings of the MRS Online Proceedings Library, vol. 885, 2005.

[26] S. Garroni, C. Milanese, A. Girella et al., "Sorption properties of $\mathrm{NaBH} 4 / \mathrm{MH} 2(\mathrm{M}=\mathrm{Mg}, \mathrm{Ti})$ powder systems," International Journal of Hydrogen Energy, vol. 35, no. 11, pp. 5434-5441, 2010.

[27] D. Pottmaier, C. Pistidda, E. Groppo et al., "Dehydrogenation reactions of $2 \mathrm{NaBH}_{4}+\mathrm{MgH}_{2}$ system," International Journal of Hydrogen Energy, vol. 36, no. 13, pp. 7891-7896, 2011.

[28] C. Bale, A. Pelton, and W. Thompson, "FactSage 6.4, Factsage thermochemical software and databases," http://www.crct .polymtl.ca/.

[29] A. San-Martin and F. D. Manchester, "The H-Mg (HydrogenMagnesium) system," Journal of Phase Equilibria, vol. 8, no. 5, pp. 431-437, 1987.

[30] K. Zeng, T. Klassen, W. Oelerich, and R. Bormann, "Critical assessment and thermodynamic modeling of the Mg-H system," International Journal of Hydrogen Energy, vol. 24, no. 10, pp. 989-1004, 1999.

[31] U. Wolf, K. Bohmhammel, and G. Wolf, "A simple adiabatic lowtemperature calorimeter based on a helium refrigerator system," Thermochimica Acta, vol. 310, no. 1-2, pp. 37-42, 1998.

[32] B. Bogdanović, K. Bohmhammel, B. Christ et al., "Thermodynamic investigation of the magnesium-hydrogen system," Journal of Alloys and Compounds, vol. 282, no. 1-2, pp. 84-92, 1999.

[33] L. Belkbir, E. Joly, and N. Gerard, "Comparative study of the formation-decomposition mechanisms and kinetics in $\mathrm{LaNi}_{5}$ and magnesium reversible hydrides," International Journal of Hydrogen Energy, vol. 6, no. 3, pp. 285-294, 1981.

[34] V. Shapovalov, N. Serdyuk, and A. Semik, "Magnesiumhydrogen and aluminum-hydrogen phase diagrams," Dopovidi Akademii Nauk Ukrains'koi RSR Seriya A: Fiziko-Matematichni ta Tekhnichni Nauki, vol. 6, pp. 99-101, 1981.

[35] J. F. Stampfer Jr., C. E. Holley Jr., and J. F. Suttle, "The magnesium-hydrogen system," Journal of the American Chemical Society, vol. 82, no. 14, pp. 3504-3508, 1960. 
[36] V. I. Shapovalov, A. P. Semik, and A. G. Timchenko, "On the solubility of hydrogen in liquid magnesium," Metally, vol. 3, pp. 25-28, 1993.

[37] J. Shefer, P. Fischer, W. Hälg et al., "New structure results for hydrides and deuterides of the hydrogen storage material $\mathrm{Mg}_{2} \mathrm{Ni}$," Journal of the Less Common Metals, vol. 74, no. 1, pp. 65-73, 1980.

[38] P. Selvam, B. Viswanathan, C. S. Swamy, and V. Srinivasan, "Studies on the thermal characteristics of hydrides of $\mathrm{Mg}$, $\mathrm{Mg}_{2} \mathrm{Ni}, \mathrm{Mg}_{2} \mathrm{Cu}$ and $\mathrm{Mg}_{2} \mathrm{Ni}_{1-x} \mathrm{M}_{x}(\mathrm{M}=\mathrm{Fe}, \mathrm{Co}, \mathrm{Cu}$ or $\mathrm{Zn} ; 0<$ $x<1$ ) alloys," International Journal of Hydrogen Energy, vol. 13, no. 2, pp. 87-94, 1988 .

[39] D. Noréus and P.-E. Werner, "The structure of the low temperature phase $\mathrm{Mg}_{2} \mathrm{NiH}_{4}(\mathrm{LT})$," Materials Research Bulletin, vol. 16, no. 2, pp. 199-206, 1981.

[40] T. Hirata, "Pressure DSC study of the hydrogenation and dehydrogenation of some intermetallic compounds $\mathrm{Mg}_{2} \mathrm{Ni}$," International Journal of Hydrogen Energy, vol. 9, no. 10, pp. 855859, 1984.

[41] A. Krozer and B. Kasemo, "Hydrogen uptake by Pd-coated Mg: absorption-decomposition isotherms and uptake kinetics," Journal of the Less Common Metals, vol. 160, no. 2, pp. 323-342, 1990.

[42] J. Koeneman and A. Metcalfe, "The solubility of hydrogen in magnesium," ASM Transactions, vol. 51, pp. 1072-1082, 1959.

[43] F. H. Ellinger, C. E. Holley Jr., B. B. McInteer et al., "The preparation and some properties of magnesium hydride," Journal of the American Chemical Society, vol. 77, no. 9, pp. 2647-2648, 1955.

[44] J. J. Reilly and R. H. Wiswall Jr., "The reaction of hydrogen with alloys of magnesium and nickel and the formation of Mg2NiH4," Inorganic Chemistry, vol. 7, no. 11, pp. 2254-2256, 1968.

[45] H. Buchner, O. Bernauer, and W. Straub, "Development of high temperature hydrides for vrhicular applications," in Proceedings of the World Hydrogen Energy Conference, pp. 1677-1687, Zürich, Switzerland, 1978.

[46] K. J. Gross, P. Spatz, A. Züttel, and L. Schlapbach, "Mechanically milled Mg composites for hydrogen storage: the transition to a steady state composition," Journal of Alloys and Compounds, vol. 240, no. 1-2, pp. 206-213, 1996.

[47] E. Akiba, K. Nomura, S. Ono, and Y. Mizuno, "Pressurecomposition isotherms of MgNiH2 alloys," Journal of The LessCommon Metals, vol. 83, no. 2, pp. L43-L46, 1982.

[48] A. S. Pedersen, J. Kjøller, B. Larsen, and B. Vigeholm, "Magnesium for hydrogen storage," International Journal of Hydrogen Energy, vol. 8, no. 3, pp. 205-211, 1983.

[49] D. F. Chernega, Y. Y. Gotvyanskii, and T. N. Prisyazhnyuk, "Hydrogen permeability, diffusion, and solubility of hydrogen in magnesium-aluminum alloys," Liteinoe Proizvodstvo, vol. 12, pp. 9-10, 1977.

[50] Y. C. Huang, T. Watanabe, and R. Komatsu, "Hydrogen in magnesium and its alloys," in Proceedings of the International Conference on Vacuum Metallurgy, pp. 176-179, 1974.

[51] E. Øvrelid, T. A. Engh, and D. Øymo, Light Metals, TMS, Warrendale, vol. PA, pp. 771-778, 1994.

[52] E. Øvrelid, G. B. Fl, T. Rosenqvist, P. Bakke, and T. A. Engh, "The effect of Sr addition on the hydrogen solubility and hydride formation in pure Mg and the alloy AZ91," Scandinavian Journal of Metallurgy, vol. 27, pp. 133-140, 1998.

[53] Z. D. Popovic and G. R. Piercy, "Measurement of the solubility of hydrogen in solid magnesium," Metallurgical Transactions A, vol. 6, no. 10, pp. 1915-1917, 1975.
[54] J.-P. Harvey and P. Chartrand, "Modeling the hydrogen solubility in liquid aluminum alloys," Metallurgical and Materials Transactions B: Process Metallurgy and Materials Processing Science, vol. 41, no. 4, pp. 908-924, 2010.

[55] A. San-Martin and F. D. Manchester, "The H-Na (HydrogenSodium) system," Bulletin of Alloy Phase Diagrams, vol. 11, no. 3, pp. 287-294, 1990.

[56] P. Roy and D. N. Rodgers, "Characterization of a diffusion tube hydrogen detector in a dynamic sodium system," Nuclear Technology, vol. 12, pp. 388-392, 1971.

[57] A. Herold, "Contribution to the study of the alkaline hydride," Ann. Chim. Set., vol. 12, pp. 537-575, 1951.

[58] E. F. Sollers and J. L. Crenshaw, "The dissociation pressures of sodium deuteride and sodium hydride," Journal of the American Chemical Society, vol. 59, no. 12, pp. 2724-2726, 1937.

[59] D. D. Williams, J. A. Grand, and R. R. Miller, "The solubility of sodium hydride in sodium," Journal of Physical Chemistry, vol. 61, no. 3, pp. 379-381, 1957.

[60] C. C. Addison, R. J. Pulham, and R. J. Roy, "19. Liquid metals. Part X. Solutions of hydrogen in liquid sodium," Journal of the Chemical Society, pp. 116-121, 1965.

[61] D. W. McClure and G. D. Halsey Jr., "The solubility of hydrogen in liquid sodium," The Journal of Physical Chemistry, vol. 69, no. 10, pp. 3542-3547, 1965.

[62] R. J. Newcombe and J. Thompson, "An electrochemical method for the determination of the solubility of hydrogen in liquid sodium," Journal of Polarographic Society, vol. 14, p. 104, 1968.

[63] S. A. Meacham, E. F. Hill, and A. A. Gardus, The Solubility or Hydrogen in Sodium, vol. APDA-241, Atomic Power Development Associates, 1970.

[64] D. R. Vissers, J. T. Holmes, L. G. Bartholme, and P. A. Nelson, "A hydrogen activity meter for liquid sodium and its application to hydrogen solubility measurements," Nuclear Technology, vol. 21, no. 3, pp. 235-244, 1974.

[65] O. A. Skuratov, O. N. Pavlov, V. 1. Danilkin, and I. V. Volkov, "Dissociation pressure of molten stoichiometric alkali metal hydrides," Journal of Inorganic Chemistry, vol. 21, pp. 1605-1608, 1976.

[66] W. Klostermeier and E. U. Franck, "Liquid mixture of sodium and sodium hydride at high pressures and temperatures," Physical Chemistry Chemical Physics, vol. 86, no. 7, pp. 606-612, 1982.

[67] V. Prochazka and M. Nedved, "Chemistry of metal hydrides. VI. Mechanism of the formation of sodium hydride catalyzed by carbon monoxide," Collection of Czechoslovak Chemical Communications, vol. 38, pp. 2850-2854, 1973.

[68] J. R. Gwyther and C. Whittingham, "The kinetics of hydrogen removal from liquid sodium," in Material Behavior and Physical Chemistry in Liquid Metal Systems, pp. 335-343, Springer, New York, NY, USA, 1982.

[69] G. F. Huttig and F. Brodkorb, "Chemistry of hydrogen. VI. Compounds of hydrogen with sodium," Zeitschrift für Anorganische und Allgemeine Chemie, vol. 161, pp. 353-362, 1927.

[70] H. Hagen and A. Sieverts, "Sodium hydride. I. Preparation and density," Zeitschrift für Anorganische und Allgemeine Chemie, vol. 185, pp. 239-253, 1930.

[71] E. Zintl and A. Harder, "Alkali hydrides", Zeitschrift für Physikalische Chemie B, vol. 14, pp. 265-284, 1931.

[72] V. G. Kuznetsov and M. M. Shkrabkina, "X-ray diffraction study of $\mathrm{NaH}$ and $\mathrm{KH}$ at temperatures from 20 to $400 \circ \mathrm{C}$," Journal of Structural Chemistry, vol. 3, no. 5, pp. 532-537, 1962. 
[73] C. Qiu, S. M. Opalka, G. B. Olson, and D. L. Anton, "The Na$\mathrm{H}$ system: from first-principles calculations to thermodynamic modeling," International Journal of Materials Research, vol. 97, no. 6, pp. 845-853, 2006.

[74] S. R. Gunn and L. G. Green, "The heats of formation at $25^{\circ}$ of the crystalline hydrides and deuterides and aqueous hydroxides of lithium, sodium and potassium," Journal of the American Chemical Society, vol. 80, no. 18, pp. 4782-4786, 1958.

[75] S. R. Gunn, "The heats of formation at $25^{\circ}$ of the crystalline hydrides and aqueous hydroxides of rubidium and cesium," The Journal of Physical Chemistry, vol. 71, no. 5, pp. 1386-1390, 1967.

[76] C. E. Messer, L. G. Fasolino, and C. E. Thalmayer, "The heats of formation of lithium, sodium and potassium hydrides," Journal of the American Chemical Society, vol. 77, no. 7, pp. 4524-4526, 1955.

[77] H. Hagen and A. Sieverts, "Sodium hydride. II. Heat of formation," Zeitschrift für Anorganische und Allgemeine Chemie, vol. 185, pp. 254-266, 1930.

[78] A. Herold, "Dissociation pressure of alkali hydrides," Comptes Rendus Chimie, vol. 228, pp. 686-688, 1949.

[79] E. V. Sayre and J. J. Beaver, "Isotope effect in the vibrational frequency spectra and specific heats of sodium hydride and deuteride," The Journal of Chemical Physics, vol. 18, no. 5, pp. 584-594, 1950.

[80] B. Predel, "H-Na (hydrogen-sodium)," in Ga-Gd-Hf-Zr, O. Madelung, Ed., pp. 1-3, Springer, Berlin, Germany, 1996.

[81] C. H. Mathewson, "Sodium-aluminum, sodium-magnesium, and sodium-zinc alloys," Zeitschrift für Anorganische und Allgemeine Chemie, vol. 48, pp. 191-200, 1906.

[82] M. F. Lantratov, "Thermodynamic properties of liquid Na-Mg and K-Mg alloys," Journal of Applied Chemistry of the USSR, vol. 46, pp. 2107-2110, 1973.

[83] W. Klemm and D. Kunze, "Systems of alkali and alkaline earth metals," in Proceedings of the International Symposium on Alkali Metals, pp. 3-22, London, UK, 1967.

[84] A. D. Pelton, "The Mg-Na (Magnesium-Sodium) system," Bulletin of Alloy Phase Diagrams, vol. 5, no. 5, pp. 454-456, 1984.

[85] S. Zhang, Q. Han, and Z.-K. Liu, "Thermodynamic modeling of the Al-Mg-Na system," Journal of Alloys and Compounds, vol. 419, no. 1-2, pp. 91-97, 2006.

[86] K. Ikeda, Y. Nakamori, and S. Orimo, "Formation ability of the perovskite-type structure in $\mathrm{Li}_{x} \mathrm{Na}_{1-X} \mathrm{MgH}_{3}$ ( $x=0,0.5$ and 1.0)," Acta Materialia, vol. 53, no. 12, pp. 3453-3457, 2005.

[87] M. D. Banus, J. J. Mcsharry, and E. A. Sullivan, "The sodiumsodium hydride-hydrogen system at 500-600", Journal of the American Chemical Society, vol. 77, no. 7, pp. 2007-2010, 1955.

[88] D. A. Sheppard, M. Paskevicius, and C. E. Buckley, "Thermodynamics of hydrogen desorption from $\mathrm{NaMgH}_{3}$ and its application as a solar heat storage medium," Chemistry of Materials, vol. 23, no. 19, pp. 4298-4300, 2011.

[89] A. T. Dinsdale, "SGTE data for pure elements," Calphad, vol. 15, no. 4, pp. 317-425, 1991.

[90] J. M. W. Chase, Ed., NIST-JANAF Thermochemical Tables, NIST, Washington, DC, USA, 1998.

[91] A. D. Pelton, S. A. Degterov, G. Eriksson, C. Robelin, and Y. Dessureault, "The modified quasichemical model I-binary solutions," Metallurgical and Materials Transactions B: Process Metallurgy and Materials Processing Science, vol. 31, no. 4, pp. 651-659, 2000.

[92] Z.-Y. Qiao, X. Xing, M. Peng, and A. Mikula, "Thermodynamic criterion for judging the symmetry of ternary systems and criterion applications," Journal of Phase Equilibria, vol. 17, no. 6, pp. 502-507, 1996.

[93] K. Frisk, "A thermodynamic evaluation of the Cr-N, Fe-N, Mo$\mathrm{N}$ and Cr-Mo-N systems," Calphad, vol. 15, no. 1, pp. 79-106, 1991.

[94] M. L. Post and J. J. Murray, " $\mathrm{Mg}_{2} \mathrm{Ni}$ hydride: in situ heat conduction calorimetry of the phase transition near $510-\mathrm{K}$," Journal of The Less-Common Metals, vol. 134, no. 1, pp. 15-26, 1987. 

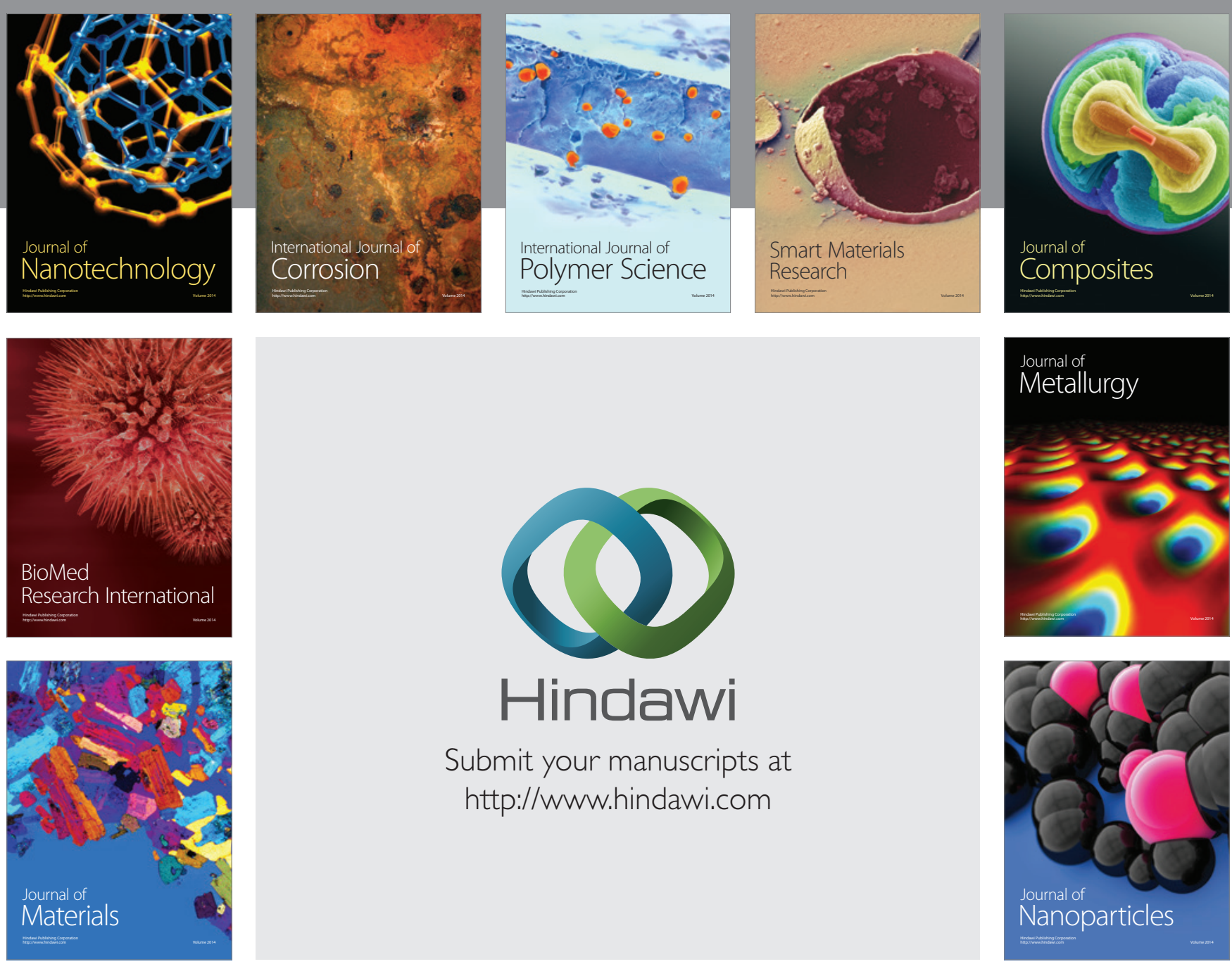

Submit your manuscripts at http://www.hindawi.com
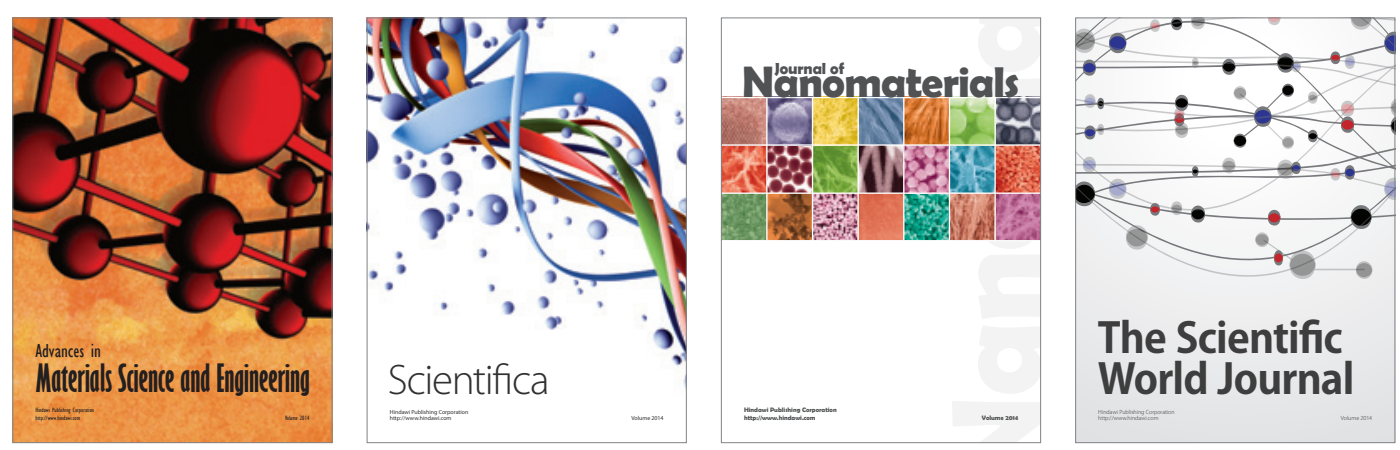

\section{The Scientific World Journal}
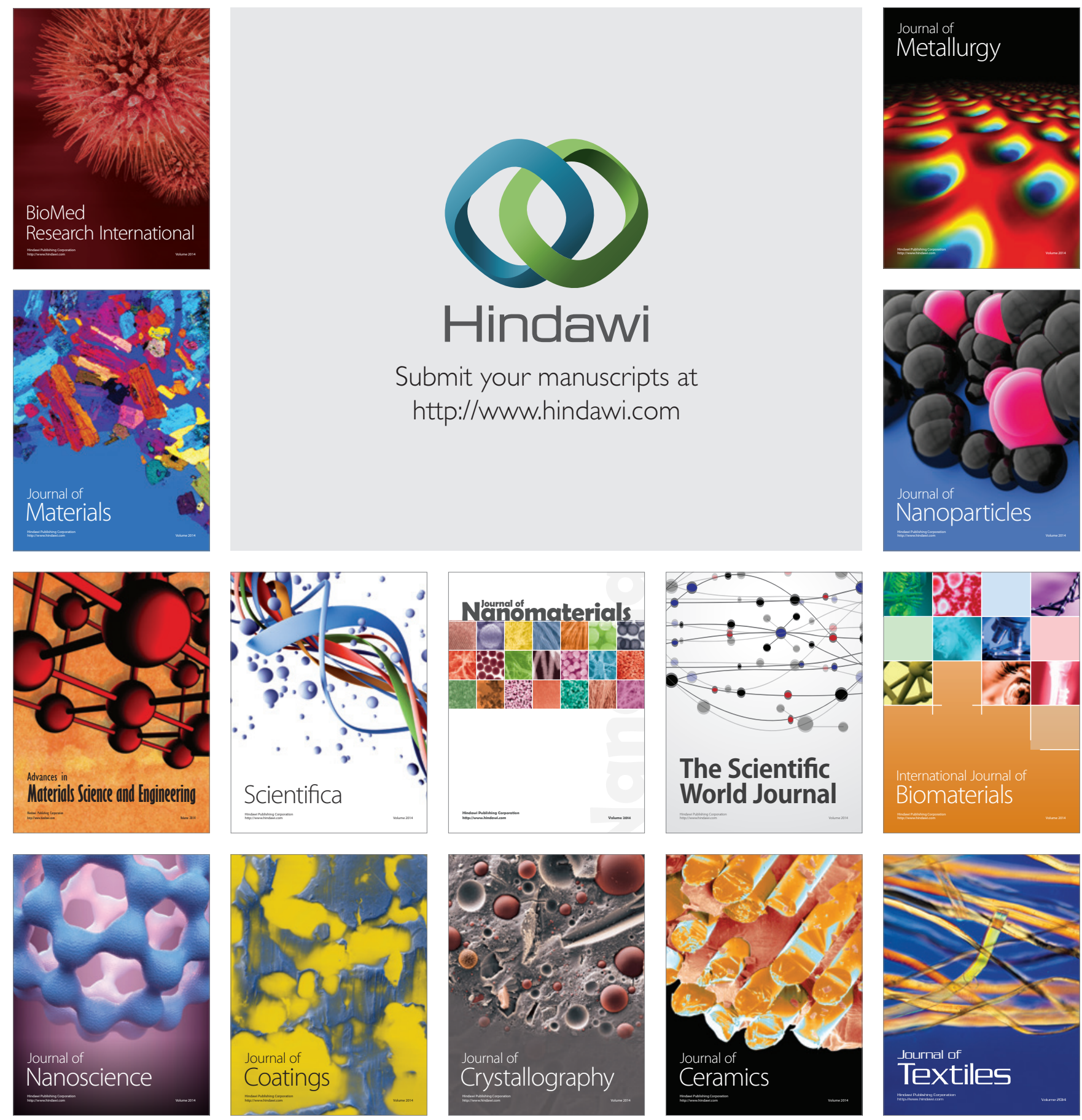